\title{
A transfer function for the prediction of gas hydrate inventories in marine sediments
}

\author{
M. Marquardt, C. Hensen, E. Piñero, K. Wallmann, and M. Haeckel \\ Leibniz-Institut für Meereswissenschaften, IFM-GEOMAR, Kiel, Germany \\ Received: 21 January 2010 - Published in Biogeosciences Discuss.: 12 February 2010 \\ Revised: 15 July 2010 - Accepted: 3 August 2010 - Published: 24 September 2010
}

\begin{abstract}
A simple prognostic tool for gas hydrate (GH) quantification in marine sediments is presented based on a diagenetic transport-reaction model approach. One of the most crucial factors for the application of diagenetic models is the accurate formulation of microbial degradation rates of particulate organic carbon (POC) and the coupled formation of biogenic methane. Wallmann et al. (2006) suggested a kinetic formulation considering the ageing effects of POC and accumulation of reaction products $\left(\mathrm{CH}_{4}, \mathrm{CO}_{2}\right)$ in the pore water. This model is applied to data sets of several ODP sites in order to test its general validity. Based on a thorough parameter analysis considering a wide range of environmental conditions, the POC accumulation rate (POCar in $\mathrm{g} / \mathrm{m}^{2} / \mathrm{yr}$ ) and the thickness of the gas hydrate stability zone (GHSZ in $\mathrm{m}$ ) were identified as the most important and independent controls for biogenic GH formation. Hence, depth-integrated $\mathrm{GH}$ inventories in marine sediments $\left(\mathrm{GHI}\right.$ in $\mathrm{g}$ of $\mathrm{CH}_{4}$ per $\mathrm{cm}^{2}$ seafloor area) can be estimated as:
\end{abstract}

$\mathrm{GHI}=a \cdot \mathrm{POCar} \cdot \mathrm{GHSZ}^{b} \cdot \exp \left(-\mathrm{GHSZ}^{c / \mathrm{POCar}} / d\right)+e$

with $a=0.00214, b=1.234, c=-3.339$,

$$
d=0.3148, e=-10.265 \text {. }
$$

The transfer function gives a realistic first order approximation of the minimum GH inventory in low gas flux (LGF) systems. The overall advantage of the presented function is its simplicity compared to the application of complex numerical models, because only two easily accessible parameters need to be determined.

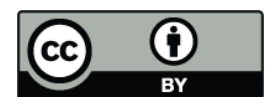

Correspondence to: M. Marquardt (mmarquardt@ifm-geomar.de)

\section{Introduction}

Submarine gas hydrates (GH) are assumed to be abundant in continental margin sediments worldwide. They have attracted increasing interest in marine geosciences for various reasons: (i) the use of $\mathrm{GH}$ as additional energy source (e.g. Bohannon, 2008; Hester and Brewer, 2009), (ii) the climate effect of melting $\mathrm{GH}$ and $\mathrm{CH}_{4}$ - release into sea water and the atmosphere induced by seafloor warming (e.g Dickens et al., 1995; Kennett et al., 2003; Milkov, 2004; Reagan and Moridis, 2009), and (iii) the potential of dissociating GH triggering slope failure events (Xu and Germanovich, 2006).

Various geochemical and geophysical methods have been developed and applied to quantify GH-inventories on various scales, however, global predictions made since the early 1980's vary extremely by several orders of magnitude $\left(5.5 \times 10^{21} \mathrm{~g}\right.$ of $\mathrm{CH}_{4}$, Dobrynin et al., $1981 ; 1.4 \times 10^{17} \mathrm{~g}$ of $\mathrm{CH}_{4}$, Soloviev, 2002). At present, an inventory between $6.7 \times 10^{17}$ and $3.3 \times 10^{18} \mathrm{~g}$ of $\mathrm{CH}_{4}(500-2,500 \mathrm{Gt}$ of $\mathrm{C})$ as estimated by Milkov (2004) still seems to be the most realistic (c.f. Archer et al., 2008). In general two different main types of marine $\mathrm{GH}$ occurrences are distinguished: high gas flux systems (HGF) and low gas flux systems (LGF) (Milkov, 2005). HGF are usually characterized by higher amounts of $\mathrm{GH}$, generally focused in permeable layers and along fractures: Kastner et al. (2008a) estimated up to $67 \mathrm{vol} \% \%$ of pore space filled by GH in sediments at the continental margin of India. Even higher concentrations of up to 90 vol.\% pore saturation are reported for sediments in the Nankai Trough (Uchida et al., 2004). Such high concentrations are the result of upward migrating fluids and gases from greater sediment depth which are often enriched in thermogenic $\mathrm{CH}_{4}$ (Sassen et al., 2001; Liu and Flemmings, 2007). In contrast, LGF seem to represent the main reservoirs for GH on a global scale. The GH in these systems consists mostly

Published by Copernicus Publications on behalf of the European Geosciences Union. 
of biogenic $\mathrm{CH}_{4}$, which is produced within and below the GHSZ. LGF encompass by far the largest area of active and passive continental margins with estimated average concentrations of about 2 vol.\% (Milkov, 2005). However, a still outstanding issue is how to explain and to predict the amount and distribution at a given location.

Since about a decade, numerical transport-reaction modelling has increasingly been used to constrain rates of GH formation and to predict GH inventories at ODP drilled sites and on global scales (e.g. Davie and Buffett, 2003; Torres et al., 2004; Buffett and Archer, 2004; Hensen and Wallmann, 2005; Klauda and Sandler, 2005; Wallmann et al., 2006; Archer et al., 2008). A striking advantage of transportreaction models is that rates of GH formation can be constrained by control parameters such as the particulate organic carbon (POC) input, POC degradation, sedimentation rate, pore water diffusion and advection, heat flow, etc., which can be calibrated against measured pore water and solid phase data. However, the majority of the available models are highly complex and depend on the knowledge of numerous site specific data. Hence, it is desirable to develop simpler approaches, which only require the availability of a few key parameters. The input and degradation of POC are critical parameters in this regard as they are the driving force for $\mathrm{CH}_{4}$ formation (Davie and Buffett, 2001). Bhatnagar et al. (2007) performed a rigorous numerical model study of LGF systems and found out that GH formation mainly depends on (i) the thickness of the GH stability zone (GHSZ), (ii) the Damkohler number, representing the ratio of methane production to methane diffusion, and (iii) the first Peclet number, representing the ratio of fluid advection to methane diffusion. While the GHSZ can be easily calculated, specifically the estimation of the rate of methane production is problematic, which makes the result of Bhatnagar et al. (2007) difficult to use without applying models of the same complexity.

In order to address this problem comprehensively, systematic investigations are required that relate the amount of GH formed in the sediments to generally available key parameters. In the present study, we test the validity of a numerical model which uses a second order rate law for POC degradation (Wallmann et al., 2006) by using geochemical pore water and solid phase data from a number of ODP drill sites. Based on this, we conducted systematic numerical model runs covering a broad range of environmental conditions and geological settings in order to derive a simplified approach for the prediction of sub-seafloor GH inventories.

\section{Numerical modelling}

\subsection{Model description}

The transport-reaction model developed by Wallmann et al. (2006) is based on a one-dimensional, numerical approach implemented in Wolfram Mathematica. Here, only a short summary of the model is presented; for an extensive descrip- tion the reader is referred to the original publication by Wallmann et al. (2006).

The model considers steady state compaction of the sediment, diffusive and advective transport of dissolved constituents, input and degradation of POC and particulate organic nitrogen (PON) via sulphate reduction and methanogenesis, anaerobic oxidation of methane (AOM), as well as the formation of $\mathrm{NH}_{4}$, dissolved inorganic carbon (DIC) and $\mathrm{CH}_{4}$. The model calculates the solubility of $\mathrm{CH}_{4}$ in pore water with respect to the stability field of GH and considers the formation and dissociation of $\mathrm{GH}$ as well as the formation and dissolution of free $\mathrm{CH}_{4}$ gas (FG) in pore water.

The POC-degradation rate is calculated as a function of POC input. The rate and reactivity of POC decrease with depth due to age-dependent alteration and inhibition by the accumulation of degradation products (i.e. DIC and $\mathrm{CH}_{4}$ ) in the pore water:

$$
\begin{aligned}
& R_{\mathrm{POC}}=\frac{K_{\mathrm{C}}}{C\left(\mathrm{CH}_{4}\right)+C(\mathrm{DIC})+K_{\mathrm{C}}} . \\
& \left(0.16 \cdot\left(\mathrm{age}_{\mathrm{init}}+\mathrm{age}_{\mathrm{sed}}\right)^{-0.95}\right) \cdot C(\mathrm{POC}),
\end{aligned}
$$

where $R_{\mathrm{POC}}$ is the degradation rate, $K_{C}$ is the inhibition coefficient for POC degradation, $C\left(\mathrm{CH}_{4}\right), C(\mathrm{DIC})$, and $C(\mathrm{POC})$ are the concentrations of the dissolved and solid species. The central term is an age-dependent term after Middelburg (1989) with age init $_{\text {as }}$ ase initial age of the POC, and age $_{\text {sed }}$ as the alteration time of POC since entering the sediment column. Specifically the predetermined parameters $K_{c}$ and age $_{\text {init }}$ are crucial for limiting POC degradation at higher concentrations of $\mathrm{CH}_{4}$ and DIC. Based on results from the Sea of Okhotsk and ODP Site 997 (Blake Ridge) Wallmann et al. (2006) could show that the $K_{c}$ value seems to be fairly constant (30 to $40 \mathrm{mM}$ ) while age init is quite variable (see Sect. 3). All other required parameters age ${ }_{\text {sed }}, C\left(\mathrm{CH}_{4}\right)$, $C$ (DIC), and $C$ (POC) are generated as model outputs.

Dissolved methane concentrations in pore water are largely determined by its solubility with respect to gas hydrate and free gas. Methane-seawater equilibrium curves in sediment are calculated after Tishchenko et al. (2005) using ambient pressure, temperature, and salinity information. When methane concentrations exceed the solubility conditions for GH or FG, GH is precipitated or FG accumulates in the pore volume. GH dissociates when it is buried below the three-phase equilibrium curve. The upward transport of the gas phase is not considered in the model. All general equations, parameterizations and boundary conditions of the model are provided in the appendix (Tables A1-A4).

\subsection{Validation of the numerical model}

The major purpose of applying the model to data from various ODP sites is to prove if a generalised parameterisation of POC kinetics is feasible to receive good fits to data from diverse geological environments. Therefore, the model was 
Table 1. Parameters, constants and coefficients of the modelled ODP Sites 1041 (Costa Rica), 685 and 1230 (Peru), 1233 (Chile), 1014 (California), 995 (Blake Ridge), and 1084 (Namibia). The values for the different model runs (constant POC input, varying POC input and fluid flow) are listed as a, b, and c. The porosity is calculated after Berner (1980) with the porosity at the surface $\left(\Phi_{0}\right)$, at the lower boundary $\left(\Phi_{f}\right)$, and the coefficient for the decrease of porosity $(\mathrm{px})$.

\begin{tabular}{|c|c|c|c|c|c|c|c|c|c|}
\hline \multirow{2}{*}{\multicolumn{3}{|c|}{$\begin{array}{l}\text { Region } \\
\text { ODP Site }\end{array}$}} & Costa Rica & \multicolumn{2}{|c|}{ Peru } & \multirow{2}{*}{$\begin{array}{l}\text { Chile } \\
1233\end{array}$} & \multirow{2}{*}{$\begin{array}{c}\text { California } \\
1014\end{array}$} & \multirow{2}{*}{$\begin{array}{l}\text { Blake Ridge } \\
\quad 995\end{array}$} & \multirow{2}{*}{$\begin{array}{c}\text { Namibia } \\
1084\end{array}$} \\
\hline & & & 1041 & 1230 & 685 & & & & \\
\hline \multicolumn{3}{|c|}{ Water depth [m] } & 3305 & 5086 & 5070 & 838 & 1165 & 2779 & 1992 \\
\hline \multicolumn{3}{|c|}{ Seafloor temperature $\left[{ }^{\circ} \mathrm{C}\right]$} & 1.9 & 1.7 & 1.4 & 5 & 4.1 & 3.6 & 3.5 \\
\hline \multicolumn{3}{|c|}{ Thermal gradient $[\% / \mathrm{km}]$} & 21.6 & 34.3 & 42 & 45 & 58 & 36.9 & 48 \\
\hline \multicolumn{3}{|c|}{ Sedimentation rate $\left(\omega_{0}\right)[\mathrm{cm} / \mathrm{kyr}]$} & 13.1 & 100 & 14.7 & 110 & 79 & 40 & 24 \\
\hline \multicolumn{3}{|c|}{ Sediment thickness $[\mathrm{m}]$} & 750 & 270 & 620 & 120 & 500 & 900 & 620 \\
\hline \multicolumn{3}{|c|}{$\mathrm{N}: \mathrm{C}$ ratio of organic matter } & $16 / 160$ & $16 / 106$ & $16 / 106$ & $16 / 145$ & $16 / 170$ & $16 / 140$ & $16 / 170$ \\
\hline \multicolumn{2}{|c|}{$\begin{array}{l}\mathrm{NH}_{4} \text { adsorption coefficient }\left(\mathrm{K}_{\mathrm{ADS}}\right) \\
\text { [ } \mathrm{cm}^{3} \text { pore water/g solids] }\end{array}$} & $\mathrm{a} / \mathrm{b} / \mathrm{c}$ & 1.3/1.9/- & $0.1 /-/-$ & $0.1 /-/ 0.1$ & $0.8 / 0.7 / 0.1$ & $0.01 /-/-$ & $0.3 / 0.6 /-$ & $0.1 /-/ 0.1$ \\
\hline \multicolumn{2}{|c|}{ POC [wt.\%] } & $\mathrm{a} / \mathrm{b} / \mathrm{c}$ & $1.6 / 1.2-3.0 * /-$ & $2.8 /-/-$ & $3.2 /-13.2$ & $1.2 / 1.1-2.1 * / 0.9-2.1$ & $5 /-/-$ & $1.6 / 0.25-1.9^{*} /-$ & $8 /-/ 8$ \\
\hline \multicolumn{2}{|c|}{ Initial age of POC (age init$)[\mathrm{kyr}]$} & $\mathrm{a} / \mathrm{b} / \mathrm{c}$ & $100 / 100 /-$ & $40 /-1-$ & $45 /-/ 20$ & $0.8 / 1.5 / 3$ & $50 /-1-$ & $180 / 25 /-$ & $43 /-/ 43$ \\
\hline \multicolumn{2}{|c|}{ POC inhibition constant $\left(\mathrm{K}_{C}\right)[\mathrm{mmol} / \mathrm{l}]$} & $\mathrm{a} / \mathrm{b} / \mathrm{c}$ & $43 / 44 /-$ & $45 /-1-$ & $43 /-/ 45$ & $50 / 45 / 45$ & $25 /-1-$ & $45 / 45 /-$ & $45 /-/ 45$ \\
\hline \multicolumn{2}{|c|}{ Fluid Flow [mm/yr] } & $\mathrm{c}$ & - & - & 0.16 & 1.1 & - & - & 0.18 \\
\hline Porosity & $\Phi_{0}$ & & 0.7 & 0.76 & 0.76 & 0.77 & 0.8 & 0.76 & 0.85 \\
\hline \multirow[t]{2}{*}{$\Phi$} & $\Phi_{f}$ & & 0.52 & 0.65 & 0.56 & 0.62 & 0.6 & 0.52 & 0.7 \\
\hline & $1 / \mathrm{px}$ & & 20000 & 5000 & 17000 & 1800 & 4000 & 17000 & 4000 \\
\hline
\end{tabular}

* Scenarios for variable POC input over time were calculated at the Costa Rica, Chile, and Blake Ridge sites using the equations below:

$\operatorname{POC}(\mathrm{t})_{1041}=1.55+1.55 \cdot \exp \left[-\left(\mathrm{t}-0.81 \cdot \mathrm{t}_{\max }\right)^{2} / 20000 / \mathrm{t}_{\max }\right]-0.45 \cdot \exp \left[-\left(\mathrm{t}-0.87 \cdot \mathrm{t}_{\max }\right)^{2} / 60000 / \mathrm{t}_{\max }\right]$

$\operatorname{POC}(\mathrm{t})_{1233}=1+1.3 \cdot \exp \left[-\left(\mathrm{t}-1.05 \cdot \mathrm{t}_{\max }\right)^{2} / 2000 / \mathrm{t}_{\max }\right]$

POC $(\mathrm{t})_{995}=1.7+0.9 \cdot \exp \left[-\left(\mathrm{t}-0.97 \cdot \mathrm{t}_{\max }\right)^{2} / 300000 / \mathrm{t}_{\max }\right]-2.9 \cdot \exp \left[-\left(\mathrm{t}-1.1 \cdot \mathrm{t}_{\max }\right)^{2} / 200000 / \mathrm{t}_{\max }\right]$

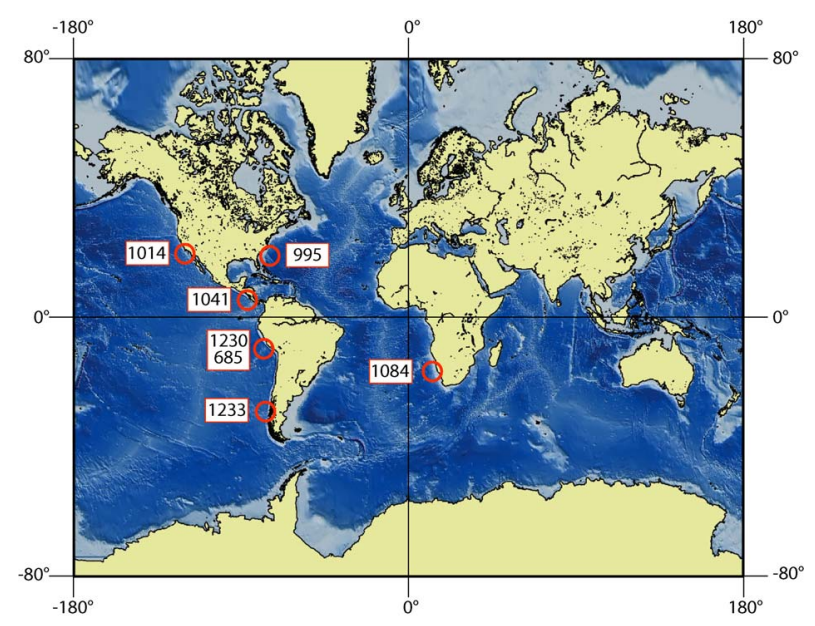

Fig. 1. Location of the ODP Sites used for the validation test of the numerical model: Blake Ridge (Site 995), Califormia (Site 1014), Costa Rica (Site 1041), Namibia (Site 1084), Peru (Sites 685, 1230), and Chile (Site 1233).

applied to data from various ODP Sites (Fig. 1): 1041 (Costa Rica), 685 and 1230 (Peru), 1233 (Chile), 1014 (California), 995 (Blake Ridge), and 1084 (Namibia). GH were previously recovered and/or confirmed at ODP Sites 1041, 685, 1230 and 995. All required environmental information comprising for example water depth (hydrostatic pressure), geothermal properties (heat flow), seafloor temperature and sedimentation rate for each site was obtained from the respective ODP reports (D'Hondt et al., 2003; Kimura et al., 1997; Lyle et al., 1997; Mix et al., 2003; Paull et al., 1996; Suess et al., 1988; Wefer et al., 1998) and is summarised in Table 1. Overall, GH-containing sedimentary strata with varying thicknesses of 200 to $800 \mathrm{~m}$ were recovered from these sites. At Site 1041 the bottom of the stability zone (BSZ) is not reached within the sedimentary deposits. In general, the overall POC concentrations are high $(>0.5 \mathrm{wt} . \%)$ and the $\mathrm{SO}_{4}$-penetration depth is low and accompanied by a strong increase of subsurface $\mathrm{NH}_{4}$ - and $\mathrm{CH}_{4}$-levels.

Each of the standard models was run into steady state by fitting the model to concentration-depth profiles of the dissolved species $\mathrm{SO}_{4}$ and $\mathrm{NH}_{4}$ and the solid species POC and PON assuming that, in general, the present day pore water profiles are representative for the sedimentary history of the system. Standard runs consider constant POC input over time as well as sediment burial and molecular diffusion as the only transport processes (a-model runs). Additional runs with variable POC input (b-model runs) and fluid advection (c-model runs) were performed as specified below (Table 1) in order to comply with site-specific conditions.

All model results (including predicted $\mathrm{GH}$ volumes) and measured concentrations of $\mathrm{SO}_{4}, \mathrm{NH}_{4}, \mathrm{POC}$, and PON (if available) are shown in Figs. 2-7. The boundary conditions used in this study are listed in Table A4 of the Appendix. For all models the concentrations at the upper boundary of the dissolved species $\mathrm{SO}_{4}, \mathrm{CH}_{4}$ and $\mathrm{NH}_{4}$ have been prescribed to fixed values corresponding to the standard seawater composition (Dirichlet conditions). At the lower 


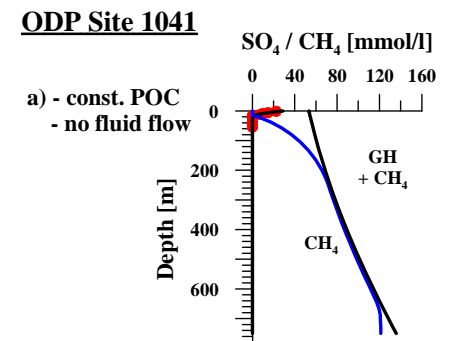

800 彗

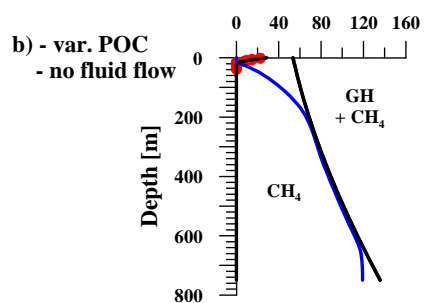

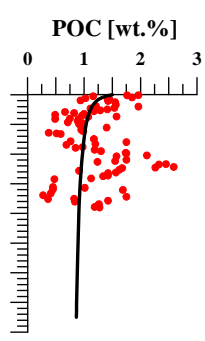

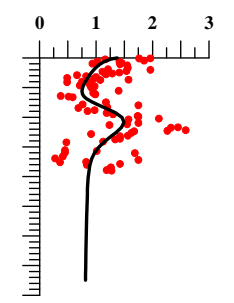

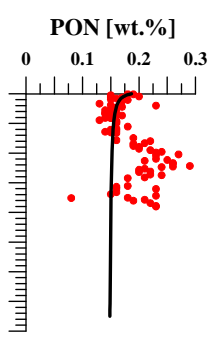

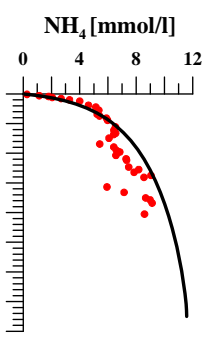

GH [vol. \%]
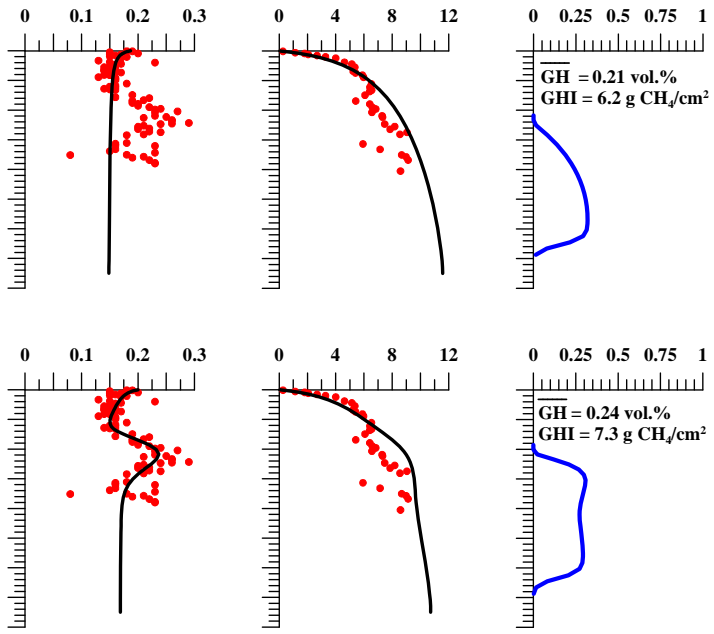

Fig. 2. Model results for ODP Site 1041 off Costa Rica for two different model runs: a) constant POC input, and b) varying POC input over time. Average $\mathrm{GH}$ concentrations $(\mathrm{GH})$ are provided in vol.\% of pore space, and as depth-integrated mass per area seafloor (GHI in $\mathrm{g}$ of $\left.\mathrm{CH}_{4} / \mathrm{cm}^{2}\right)$.

boundary zero-gradient conditions are chosen for the a- and b-models (Neumann conditions). For the c-models, which consider advective fluid flow from below, the concentrations of the dissolved species have been determined as Dirichlet conditions. Therefore, the $\mathrm{SO}_{4}$ - concentration at the lower boundary was set to zero, $\mathrm{NH}_{4}$-concentration was taken from the respective ODP data, and $\mathrm{CH}_{4}$-concentration was taken from the output of the respective a-model. The input of POC at the upper boundary is given by a fixed concentration, which is modulated into a time-dependent function considering variations in the POC input over time for the b-models (Table 1):

$$
\operatorname{POC}(x=0)=f(t)
$$

The PON input was determined by fitting the $\mathrm{N}: \mathrm{C}$ ratio of organic material to the respective POC-PON-data at each site.

Pore water $\mathrm{SO}_{4}$ and $\mathrm{NH}_{4}$ are the most important parameters for fitting the model. POC and PON usually show more natural variability, and hence are more difficult to constrain. At the depth where $\mathrm{CH}_{4}$-saturation with respect to methane hydrate is reached GH starts to precipitate. Average GH concentrations without considering fluid flow are generally below $1 \%$ of the pore volume (Figs. 2-7). These comparatively low concentrations are in agreement with recent studies at locations which are not affected by intense fluid or gas flow (Milkov, 2005; Tréhu et al., 2004).

\subsubsection{Site-specific results}

\section{Costa Rica}

ODP Site 1041 is located at the active, erosive continental margin of Costa Rica at a water depth of about $3300 \mathrm{~m}$. The site is characterised by relatively low sedimentation rates of about $13 \mathrm{~cm} / \mathrm{kyr}$ (Kimura et al., 1997). Measured data at this location are largely represented by the standard model (Fig. 2). However, POC and PON data indicate considerable variations in the input of organic material over time. In order to evaluate to which extent such variations may affect GH inventories a second run was performed where the POC input at the sediment surface was varied over time (see Table 1). The result is a better fit of POC and PON data than in the a-model, which, however, only affects estimated GH concentrations by about $20 \%$ of the total GH amount. Slight deviations from the measured $\mathrm{NH}_{4}$ profile in both runs may be explained by lateral advection of fluids (Hensen and Wallmann, 2005), which may explain local GH enrichments between 115 and $165 \mathrm{mbsf}$ at this site (Kimura et al., 1997). However, because this process is probably of minor importance and also very difficult to constrain, it will not be further addressed in this study.

\section{Peru}

The ODP Sites 1230 and 685 are located on the lower slope of the Peru margin at about $5100 \mathrm{~m}$ water depth (D'Hondt et al., 2003). Both sedimentary sequences are part of the accretionary wedge that forms due to subduction of the Nazca plate. The sedimentation rates are about $100 \mathrm{~cm} / \mathrm{kyr}$ and $14.7 \mathrm{~cm} / \mathrm{kyr}$, respectively (D'Hondt et al., 2003; Suess et al., 1988). GH was reported at site 685 in discrete layers at 99 and $165 \mathrm{mbsf}$ (Suess et al., 1988) and at site 1230 between 82 and 148 mbsf (D'Hondt et al., 2003). At Site 1230, $\mathrm{SO}_{4}$ and $\mathrm{NH}_{4}$ profiles are well reproduced by the standard model (Fig. 3). An average of the measured POC concentrations 


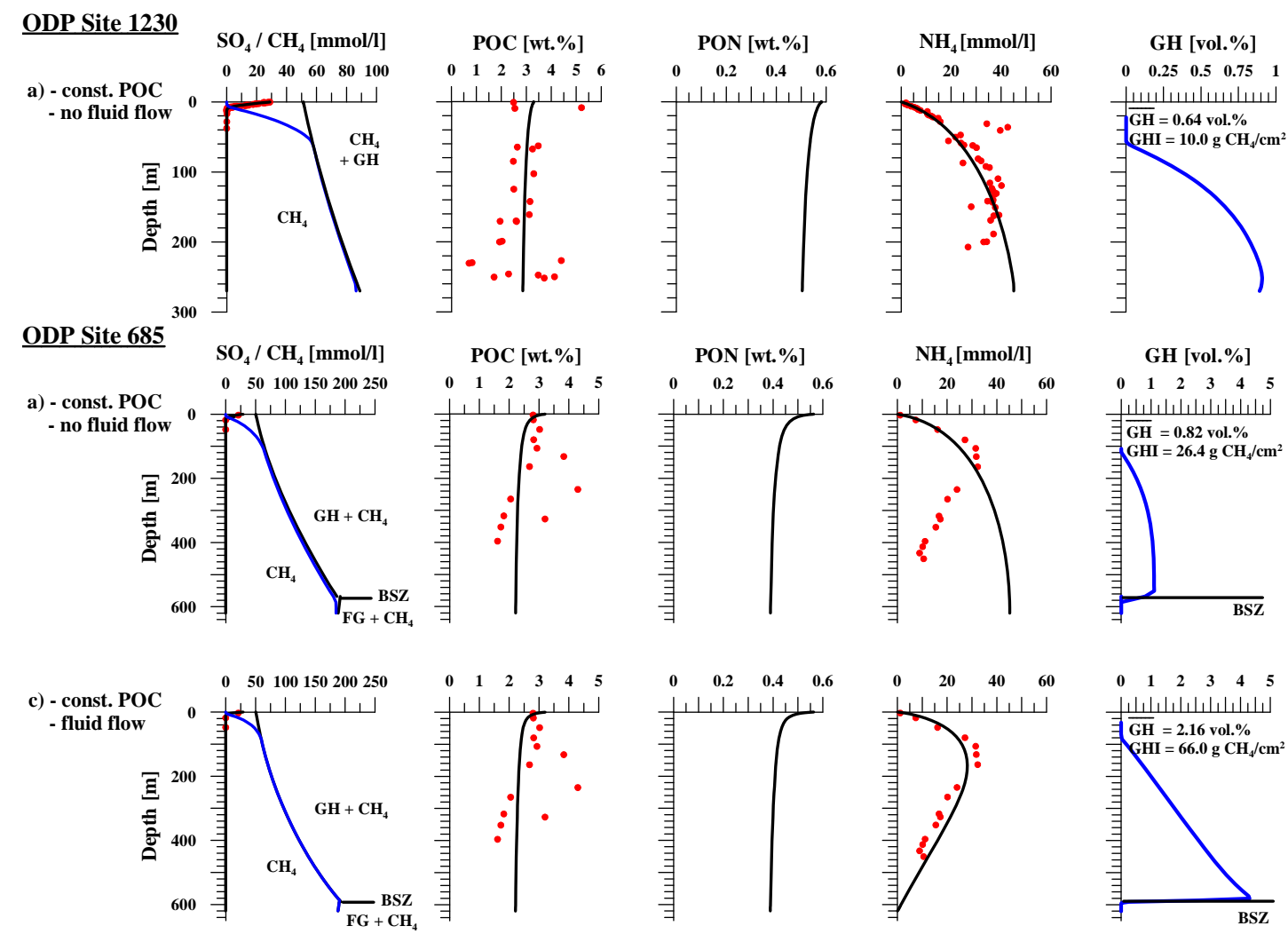

Fig. 3. Model results for ODP Sites 1230 and 685 off Peru for two different model runs: (a) constant POC input, and (c) constant POC input with advective fluid flow.

was used as the POC input value in order to comply with the considerable scatter observed in the depth profile. The GH content is 0.64 vol.\% on average and extends from about 60 to $260 \mathrm{mbsf}$, which excellently matches with the depth interval reported for GH findings (D'Hondt et al., 2003). However, the sedimentary sequence recovered at the nearby Site 685 is considerably thicker $(620 \mathrm{~m})$ and indicates that $\mathrm{NH}_{4}$ decreases with depth (Fig. 3). A model run without fluid flow results in a $\mathrm{NH}_{4}$-profile which is not supported by the data, but reveals GH concentrations purely based on in situ degradation rates (Fig. 3). Average GH inventories in the noflow scenarios are approximately the same at both locations, and hence give an approximation of minimum GH inventories. Based on drilling results (D'Hondt et al., 2003) and similar to findings offshore Costa Rica (Hensen and Wallmann, 2005), upward advection of deep-seated $\mathrm{NH}_{4}$-depleted fluids is a likely explanation for the observed decrease in $\mathrm{NH}_{4}$. In a second model run, we applied an upward advection rate of $0.16 \mathrm{~mm} / \mathrm{yr}$ and varied the model parameterisation accordingly in order to fit the model to the $\mathrm{NH}_{4}$ data (Table 1). In agreement with previous studies (Buffett and Archer, 2004; Hensen and Wallmann, 2005) GH inventories in this scenario increase significantly from $26 \mathrm{~g}$ of $\mathrm{CH}_{4} / \mathrm{cm}^{2}$ (a-model) to $66 \mathrm{~g}$ of $\mathrm{CH}_{4} / \mathrm{cm}^{2}$ (c-model) considering fluid flow.

\section{Southern Chile}

Site 1233 is located in a small forearc basin on the upper continental margin ( $840 \mathrm{mbsf}$ ) offshore southern Chile, belonging to the southern end of the Nazca subduction system. The area is characterised by very high sedimentation rates of about $100 \mathrm{~cm} / \mathrm{kyr}$. Although the pore water chloride profile may indicate the presence of GH in the sediment no GH findings are reported (Mix et al., 2003). The standard model does not produce a good fit to the POC, $\mathrm{PON}$ and $\mathrm{NH}_{4}$-data and does not predict any formation of GH (Fig. 4). The mismatch is obviously caused by changes in the POC input over time and, considering the down-core decrease of $\mathrm{NH}_{4}$, most likely fluid advection. Increasing the POC input over the past 20000 years (derived from the POC-data and the sedimentation rate), however, improved the fit to the data, but did not change the result with respect to GH accumulation. Additional consideration of fluid flow results in a good fit to the data (c-model in Fig. 4) and predicts the presence of minor amounts of GH between 60 and 80 mbsf. All in all, the in situ production of $\mathrm{CH}_{4}$ is most likely not sufficient to produce $\mathrm{GH}$ at this site, which is in agreement with field observations. 


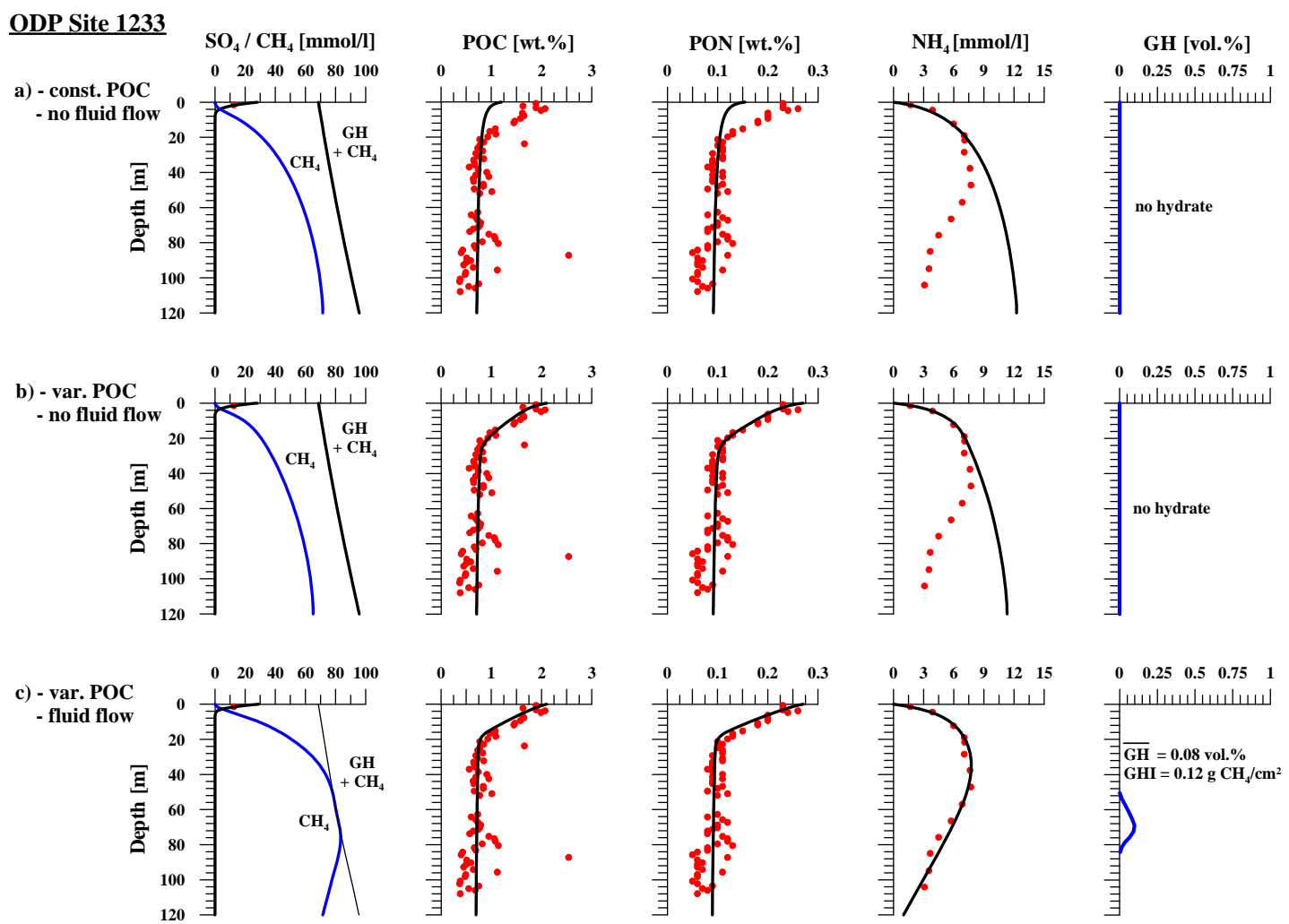

Fig. 4. Model results for ODP Sites 1233 off Chile for three different model runs: (a) constant POC input, (b) varying POC input, and (c) varying POC input combined with advective fluid flow.

\section{California}

Site 1014 was drilled in a water depth of $1165 \mathrm{~m}$ in the Tanner Basin, which belongs to the band of California Borderland basins and is characterised by high organic matter input, a high sedimentation rate of $79 \mathrm{~cm} / \mathrm{kyr}$, and an extended oxygen minimum zone between 500 and $1500 \mathrm{~m}$ water depth (Lyle et al., 1997). The standard model revealed a good fit to the measured data (Fig. 5). However, the scatter in the POC input over time was not resolved in the a-run. An average input value of $5 \mathrm{wt} . \%$ of POC produced an excellent fit to the measured $\mathrm{NH}_{4}$ profile, and hence is obviously a good approximation of the overall POC degradation. In spite of the high POC accumulation, GH are not reported for this site. Most likely this is due to the high geothermal gradient of $58 \% \mathrm{~km}$ resulting in a thin GHSZ $(175 \mathrm{~m})$. The model predicts minor amounts of GH above the BSZ.

\section{Blake Ridge}

The Blake Ridge ODP Site 995, which was drilled into a large drift deposit located at the passive continental margin of the south-eastern United States at a water depth of $2779 \mathrm{~m}$, has been studied in detail with respect to GH in the past (e.g. Dickens et al., 1997; Egeberg and Dickens, 1999). Using an average sedimentation rate of $40 \mathrm{~cm} / \mathrm{kyr}$ (Paull et al., 1996) and a constant POC and PON input in the basic a-model run does not comply with the measured data and did not predict any GH formation (Fig. 6). In addition, a very high initial sediment age of $180 \mathrm{kyr}$ had to be used in order to achieve POC degradation rates that enable a good fit to the measured $\mathrm{NH}_{4}$ profile. Using a reduced POC/PON input for the Late Quaternary (Paull et al., 2000) required higher overall degradation rates in order to fit the $\mathrm{NH}_{4}$ data and predicted $\mathrm{GH}$ formation in the depth range reported previously (Paull et al., 1996). Moreover, Wallmann et al. (2006) used the same model approach as in the present study and predicted roughly the same amount of in situ formed GH for the nearby ODP Site 997 (on average $0.3 \mathrm{vol} . \% \cong 5.1 \mathrm{~g}$ of $\mathrm{CH}_{4} / \mathrm{cm}^{2}$ ). However, overall GH inventories may be much higher (up to several 8 vol. $\% \cong 137 \mathrm{~g}$ of $\mathrm{CH}_{4} / \mathrm{cm}^{2}$; Paull et al., 2000) due to local enrichments caused by upward migration of free gas formed below the BSZ (Wallmann et al., 2006).

\section{Namibia}

Site 1084 is located on the upper continental margin off Namibia, a region which is characterised by intense upwelling and enhanced POC deposition. Likewise, average POC concentrations of $>5 \mathrm{wt} . \%$ are observed throughout the entire core, resulting in high degradation and GH formation 

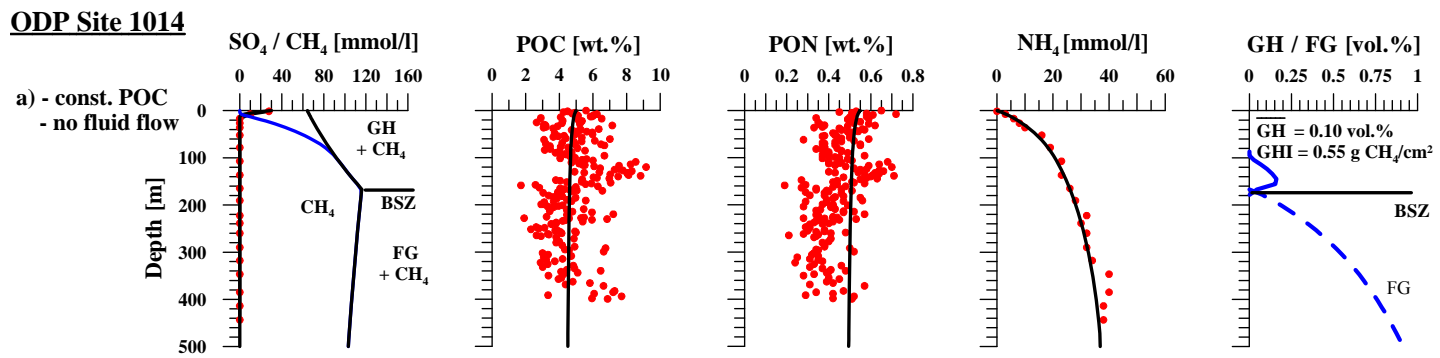

Fig. 5. Model results for ODP Site 1014 off California with (a) constant POC input. The dotted line indicates the free gas (FG) contents below the base of the GHSZ (BSZ) in \% of the pore space.

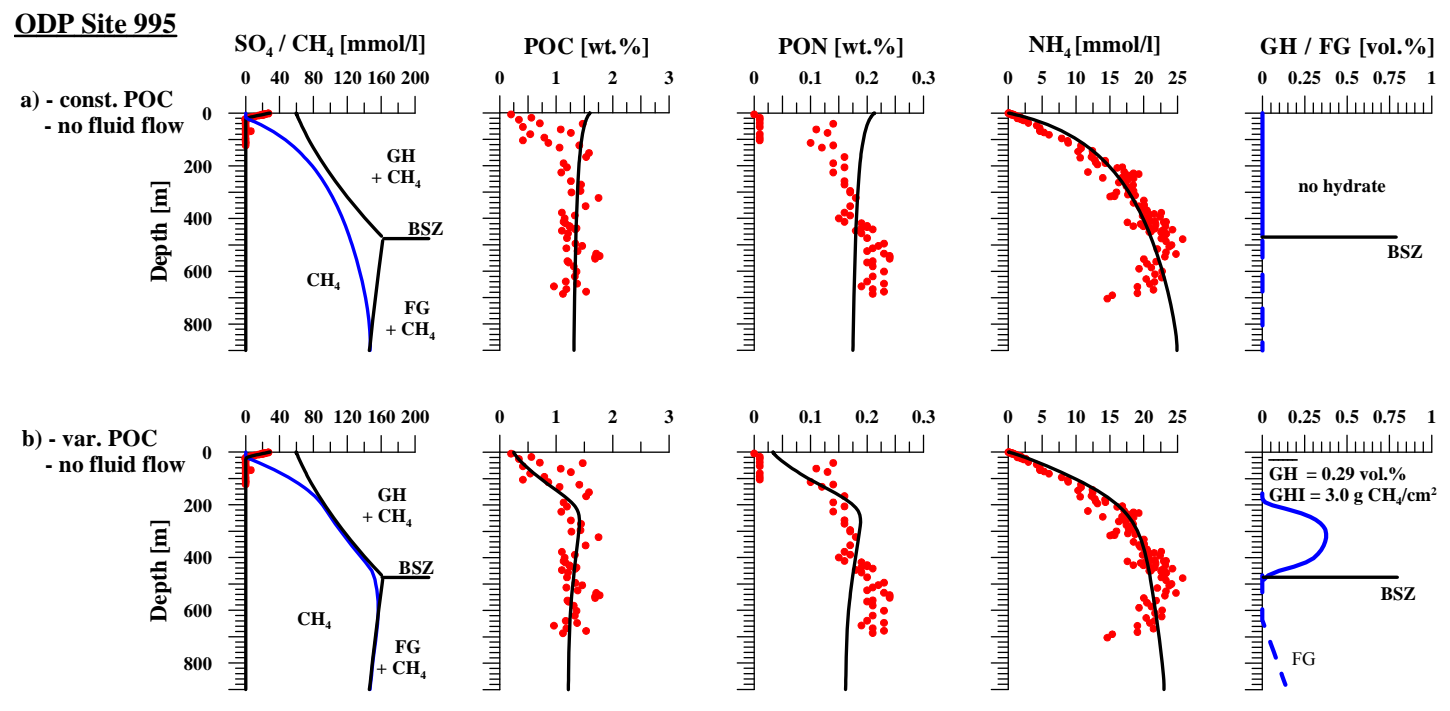

Fig. 6. Model results for ODP Site 995 at Blake Ridge for two different model runs: (a) constant POC input, and (b) time varying POC input.

rates. The sedimentation rate at this site is $24 \mathrm{~cm} / \mathrm{kyr}$ (Wefer et al., 1998). Similar to Sites 685 and 1233 (Figs. 3 and 4) the $\mathrm{NH}_{4}$ profile indicates upward fluid advection at this location. Indeed, during the drilling no findings of gas hydrate have been reported. Applying fluid advection to the model leads to a better fit of the $\mathrm{NH}_{4}$ profile and predicts about $60 \%$ higher GH amounts (Fig. 7).

The results above clearly demonstrate the general validity of the kinetic model. The model is able to reproduce the concentrations of solid and dissolved species of the ODP Sites in a generalised way, while all parameters of the kinetic rate law (Eq. 1, Table 1) are kept almost constant. Hence, the model serves as a useful basis for a systematic analysis of biogenic $\mathrm{GH}$ formation and the derivation of an analytical transfer function to predict submarine $\mathrm{GH}$ inventories. Overall, $\mathrm{GH}$ concentrations resulting from all model runs at the ODP Sites without fluid flow vary between 0 and $26 \mathrm{~g}$ of $\mathrm{CH}_{4} / \mathrm{cm}^{2}$ ( 0 to 1.6 vol.\%). In some cases, fitting the $\mathrm{NH}_{4}$ profiles required the implementation of upward fluid flow, which increases the $\mathrm{GH}$ amount up to $66 \mathrm{~g}$ of $\mathrm{CH}_{4} / \mathrm{cm}^{2}$ ( 2.2 vol.\%; Fig. 3). Al- though very significant in terms of GH formation, fluid flow is very difficult to constrain and predict on regional to global scales, and hence was neglected in the following systematic analysis. Consequently, all results presented here have to be regarded as minimum estimates, which only reflect pure biogenic methane and GH formation within the GHSZ.

\section{Sensitivity analysis of the standardised numerical model}

In order to identify the most important parameters, which significantly control the formation of $\mathrm{GH}$, a sensitivity analysis was performed with parameter variations covering a wide range of natural environments. This analysis is based on a standardised model set up (Table 2), which is defined by the average values of the environmental and chemical conditions (i.e. water depth, thermal conditions, POC concentration, POC initial age $\left(\right.$ age $\left._{\text {init }}\right)$, porosity, sedimentation rate, inhibition constant of POC degradation $\left(K_{C}\right)$ ) of the ODP models (Table 1). Critical parameters for generalization purposes are 

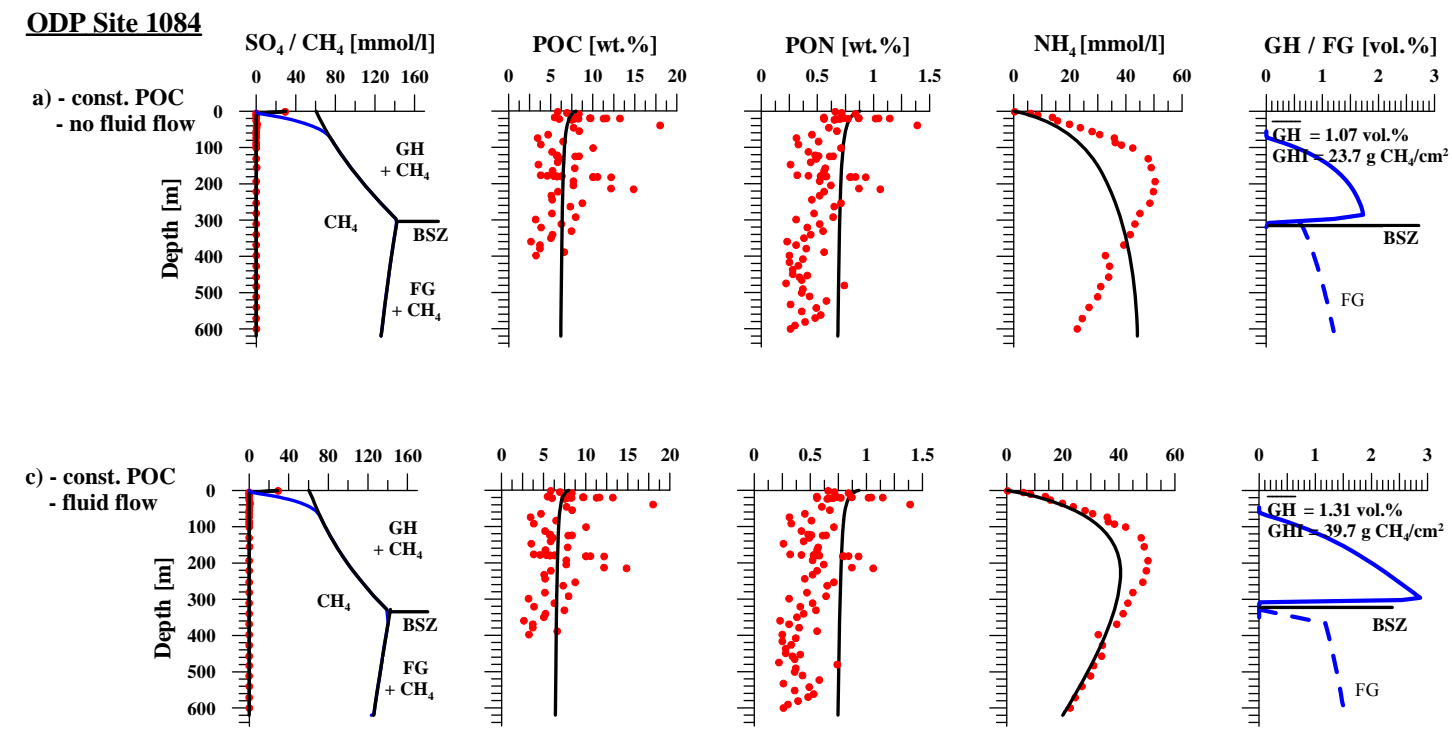

Fig. 7. Model results for ODP Site 1084 off Namibia for two different model runs: (a) constant POC input, and (c) constant POC input combined with advective fluid flow.

Table 2. Input parameters and boundary conditions for the standard model using average values of all specific ODP models. The range of parameter values used for the sensitivity analysis are also shown.

\begin{tabular}{lcc}
\hline & $\begin{array}{c}\text { Standard model } \\
\text { (average of ODP models) }\end{array}$ & $\begin{array}{c}\text { Sensitivity } \\
\text { analysis }\end{array}$ \\
\hline Water depth $[\mathrm{m}]$ & 2516 & $500-5500$ \\
Seafloor temperature $\left[{ }^{\circ} \mathrm{C}\right]$ & 3.1 & $1-6.5$ \\
Thermal gradient $\left[{ }^{\circ} / \mathrm{km}\right]$ & 44.2 & $10-65$ \\
GHSZ $[\mathrm{m}]$ & 450 & $50-2000$ \\
POC accumulation rate $\left[\mathrm{g} / \mathrm{m}^{2} / \mathrm{yr}\right]$ & 4.3 & $0.7-40$ \\
$\quad$ POC input $[\mathrm{wt} . \%]$ & 2.3 & $0.5-5.5$ \\
$\quad$ Sedimentation rate $\omega_{0}[\mathrm{~cm} / \mathrm{kyr}]$ & 32 & $9.5-200$ \\
Initial age of POC $($ age & 43.7 \\
Porosity $\Phi(\mathrm{kyr}]$ & $\left.4 \Phi_{0}, \Phi_{f}, 1 / \mathrm{px}\right)$ & $0.75,0.59,5000$ \\
$\mathrm{NH}_{4}$ adsorption coefficient $\left(\mathrm{K}_{\mathrm{ADS}}\right)\left[\mathrm{cm}^{3} / \mathrm{g}\right]$ & $0.75,0.59,5000$ & 0.52 \\
POC Inhibition constant $\left(\mathrm{K}_{C}\right)[\mathrm{mmol} / \mathrm{l}]$ & 0.52 & 43.7 \\
\hline
\end{tabular}

the age init $_{\text {and }} K_{C}$ since they may have a substantial effect on GH formation rates. In general, high $K_{C}$ and low age init values favour higher degradation rates of organic matter, going along with enhanced formation of $\mathrm{NH}_{4}, \mathrm{CH}_{4}, \mathrm{GH}$, a shallow sulphate penetration depth, and vice versa. A sensitivity

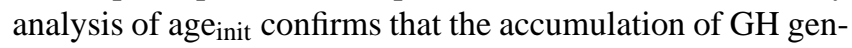
erally increases with decreasing initial POC ages (Fig. 8). The effects are strong at high sedimentation rates and comparably small in slowly accumulating sediments. Most of

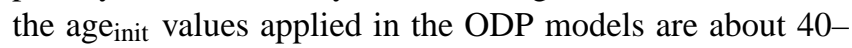
$50 \mathrm{kyr}$, with a few exceptions to higher (a- and b-model of Site 1041 and a-model of Site 995) and lower initial ages (Site 1233), and hence an average value of all ODP models ( $43.7 \mathrm{kyr}$ ) was used in the standard model. The average $K_{C}$ value in the ODP model runs is $43.7 \mathrm{mM}$ with a quite narrow range of 25 to $50 \mathrm{mM}$, which is in agreement with results of Wallmann et al. (2006).

Subsequently, the effect on the GH formation was analysed by varying water depth, thermal conditions, sedimentation rate, and POC concentration of the standard model. In these scenarios, the thermal gradient ranges from 10 to $65^{\circ} / \mathrm{km}$, the seafloor temperature from 1 to $6.5^{\circ} \mathrm{C}$, and the water depth from 500 to $5500 \mathrm{~m}$. The total sediment thickness was always chosen to be thick enough to include the entire GHSZ. The POC input concentration has been varied from 0.5 to $5.5 \mathrm{wt} . \%$. The sedimentation rate ranges from 9.5 to $200 \mathrm{~cm} / \mathrm{kyr}$. All parameter variations are listed in Table 2 . 

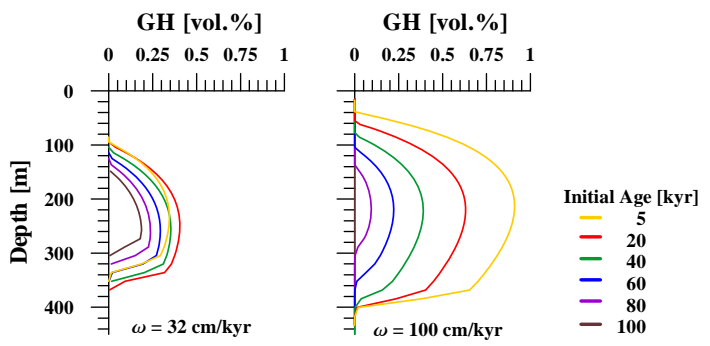

Fig. 8. Effect of the POC initial age (age $\mathrm{anit}_{\text {in }}$ ) on the accumulation of gas hydrates in marine sediments at two different sedimentation rates $(\omega)$.

In Figure 9 the relation between the tested parameters and the calculated GH amount is summarised. The amount or inventory of gas hydrates ( $\mathrm{GHI}$ in $\mathrm{g}$ of $\mathrm{CH}_{4} / \mathrm{cm}^{2}$ ) is calculated by integrating the hydrate concentrations in each layer over the entire model column. The seafloor temperature and the thermal gradient show a negative correlation with GHI because higher temperatures reduce the extension of the GH stability field. Similarly, the GHSZ thickens with increasing water depth because of increasing environmental pressure. Overall, a thick GHSZ causes a longer residence time of POC, and hence favours the formation of biogenic $\mathrm{CH}_{4}$ within it. The sole effect of the sedimentation rate on the GH formation is comparatively low. For sedimentation rates up to $75 \mathrm{~cm} / \mathrm{kyr}$ there is a positive correlation with GHI (up to $2.6 \mathrm{~g}$ of $\mathrm{CH}_{4} / \mathrm{cm}^{2}$ ) because of increasing burial of POC. However, as discovered previously by Davie and Buffett (2001), further increasing sedimentation rates (without increasing POC input at the sediment surface) lead to decreasing GH inventories; this transition into a negative trend when reaching a critical maximum at about $60 \mathrm{~cm} / \mathrm{kyr}$ is due to the reduced residence time of the degradable POC within the GHSZ, and hence limits the enrichment of $\mathrm{CH}_{4}$ and $\mathrm{GH}$.

The sulphate methane transition zone (SMT) shows no clear and useful relationship to GH formation (Fig. 9). Bhatnagar et al. (2008) showed for advective systems (HGF) that there should be a link between present-day $\mathrm{CH}_{4}$ fluxes across the SMT and the occurrence of gas hydrate in the deeper subsurface, if certain environmental conditions governing the gas hydrate system have remained constant over long periods of time. The SMT is affected by the methane flux from below and the sulphate reduction occurring in the uppermost sediment layers. Hence, high rates of POC degradation at shallow depth will consume much of the sulphate, but simultaneously reduce the potential of methane formation at greater depth. The results presented in Fig. 9 indicate that the SMT decreases with increasing sedimentation rate up to a certain threshold value $(\sim 7.5 \mathrm{~m})$ and increases, if this value is exceeded (see above). This may suggest an inefficient use of POC by sulphate reduction at very high sedimentation rates. Essentially, our results indicate that the SMT is not a simple measure for the abundance of GH; at least not in LGF set-
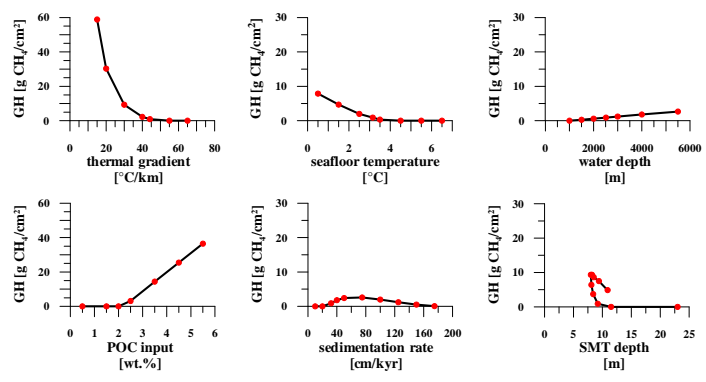

Fig. 9. Sensitivity analysis of the standard model: For each model run (red dots) only one input parameter was varied. Additionally, the output parameter $\mathrm{SO}_{4}-\mathrm{CH}_{4}$-transition depth (SMT) as a result of increasing the POCar is shown.

tings. This is in line with results of Kastner et al. (2008b) and Dickens and Snyder (2009). The latter authors, however, pointed out that pore water chemistry data may help to understand the formation of the underlying gas hydrate system, but generally not as a proxy for the amount and distribution of gas hydrate.

The other tested parameters display clear functional relationships to the calculated GH concentration (Fig. 9). However, for the derivation of a simple and useful transfer function it is crucial to limit the set of parameters to those which have (i) a strong effect on the formation of GH and (ii) are widely available and easy to determine. Moreover, the sensitivity analysis above suffers from a lack of systematics; for example POC concentration and sedimentation rate or water depth and bottom water temperature have been treated as independent parameters although they are correlated. Hence, in order to perform a refined and more robust analysis, we summarised the parameters defining the temperature and pressure conditions (water depth, thermal gradient and sediment surface temperature) into one parameter which then defines the thickness of the GHSZ (in the following just GHSZ). In addition, the general correlation between POC concentration and sedimentation rate (Henrichs 1992; Tromp et al., 1995; Burdige, 2007) was accounted for by combining these parameters into the POC accumulation rate (POCar). Since all other parameters are either intrinsically considered (because they are not independent), such as the SMT, or may have only a minor additional effect on GH formation, such as the porosity, they have been excluded from the subsequent analysis.

\section{Derivation of the transfer function}

In a second and more detailed parameter analysis the effect of POCar and GHSZ was analysed in a number of runs of the standardised numerical model by covering a wider range of natural variations of these parameters than in typical continental margin environments: GHSZ from 100 to $2000 \mathrm{~m}$ (Dickens, 2001) and POCar from 0.8 to $37.4 \mathrm{~g} / \mathrm{m}^{2} / \mathrm{yr}$ 


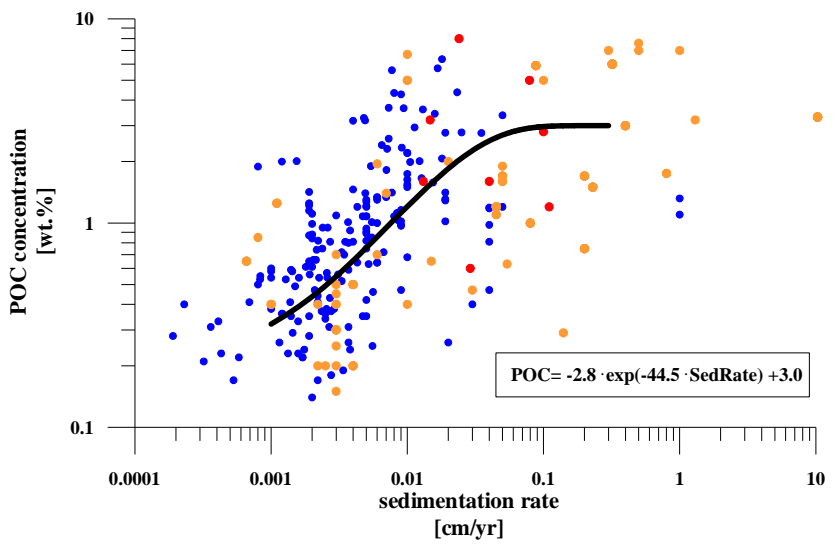

Fig. 10. POC concentrations vs. sedimentation rates after Seiter et al. (2004) (blue dots), Colman and Holland (2000) (yellow dots), and the ODP Sites used in this study (red dots) (references are listed in the text). The black line indicates the function derived for the sensitivity analysis of the numerical model.

(Seiter et al., 2005). The GHSZ was varied by changing the thermal gradient from 10 to $65^{\circ} / \mathrm{km}$, the seafloor temperature from 1 to $6^{\circ} \mathrm{C}$, and the water depth from 500 to $6000 \mathrm{~m}$. In order to identify possible interdependencies between POCar and GHSZ, crosswise variations were calculated. Because the POCar is defined by the POC concentration and the sedimentation rate, the input concentration of POC was derived by an analytical function of the sedimentation rate based on data from Seiter et al. (2004) and Colman and Holland (2000) (Fig. 10). Although the plot reflects a large range of natural variations of POC concentrations at the sediment surface (average of the upper $10 \mathrm{~cm}$ ), POC shows a general correlation with the sedimentation rate, which can be expressed by:

$\mathrm{POC}=-2.8 \cdot \exp (-44.5 \cdot \omega)+3.0$

where POC is in wt.\% and $\omega$ is the sedimentation rate in $\mathrm{cm} / \mathrm{yr}$. Equation (3) was applied for sedimentation rates between 10 and $200 \mathrm{~cm} / \mathrm{kyr}$, which corresponds to POC contents between 1.2 and $3.1 \mathrm{wt} . \%$ and POCar variations between 0.8 and $37.4 \mathrm{~g} / \mathrm{m}^{2} / \mathrm{yr}$. The great advantage of this approach is that POC data are ubiquitously available from global compilations (e.g. Premuzic et al., 1982; Seiter et al., 2004; Romankevic et al., 2009), which enable a reasonable estimate of the sedimentation rate, and hence of POCar at almost any location of the seafloor. However, it must be noted that the POC concentration at the sediment surface does not always reflect the long-term average, which is at least determining the formation potential of GH. Nevertheless, at the Chile margin and Blake Ridge sites (Figs. 4 and 6), which show a significant change of POC input over time, the overall effect on the formed GH quantities is comparatively low, which indicates that the estimation of POCar from recent values will give a reasonable approximation.
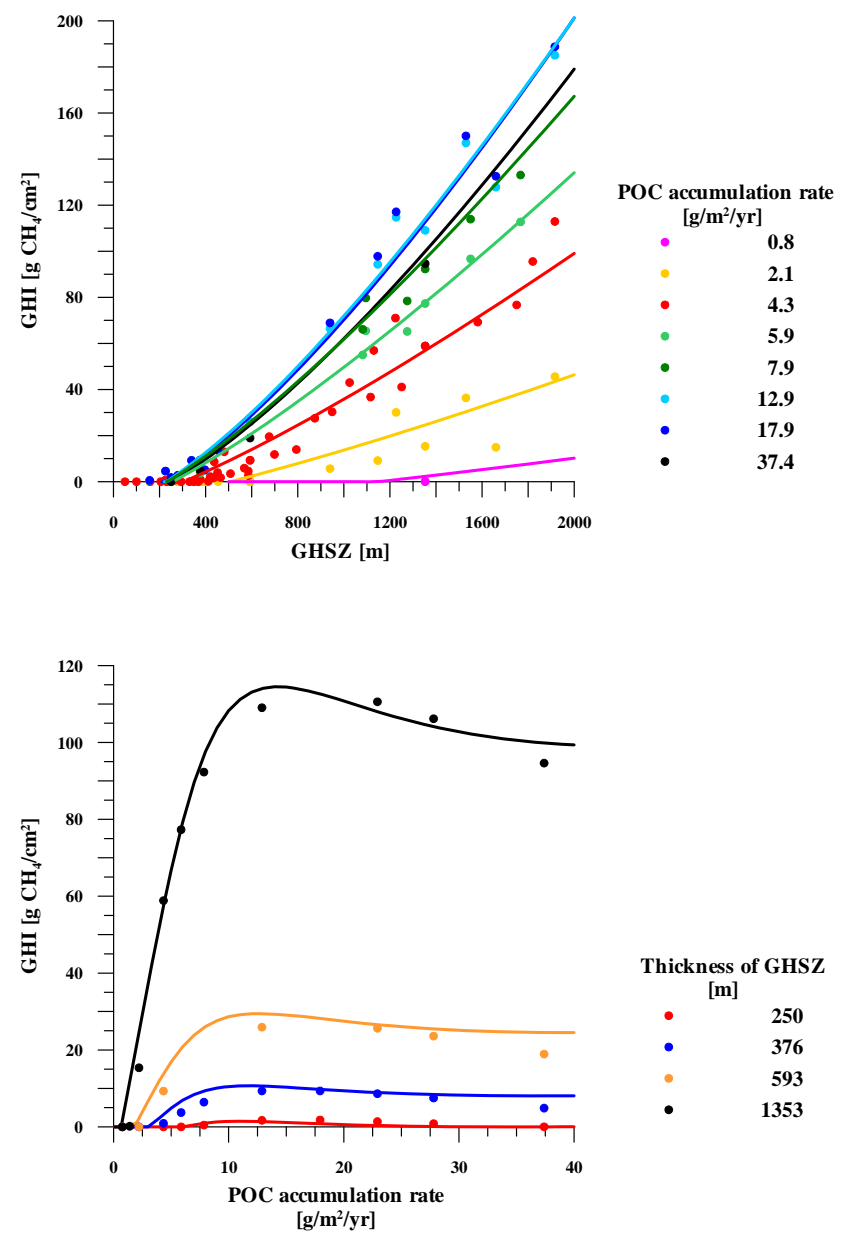

Fig. 11. Parameter analysis of the two key control parameters POCar and GHSZ: (a) relation of GHSZ and GH accumulation for varying POCar; (b) relation of POCar and GH accumulation for varying GHSZ.

The functional relationship between the GHSZ and GHI is shown in Fig. 11a. Generally, the plot shows that at constant POCar the amount of GH increases with the thickening of the GHSZ, because of the longer residence time of the degradable material within a thicker GHSZ. Higher POCar causes more GH being formed in the sediment and the gradient increases for higher POCar. It is remarkable, however, that GHI increases only for POCar up to $10-15 \mathrm{~g} / \mathrm{m}^{2} / \mathrm{yr}$. The gradient decreases again for POCar $>15 \mathrm{~g} / \mathrm{m}^{2} / \mathrm{yr}$ (dark blue and black lines in Fig. 11a), most likely because for such high POCar (sedimentation rates $>70-100 \mathrm{~cm} / \mathrm{kyr}$ ) the residence time of organic matter within the GHSZ decreases significantly. Overall, this effect is in agreement with results of Davie and Buffet (2001) and Bhatnagar et al. (2007).

In general, higher POCar leads to a higher POC degradation rate and therefore to enhanced formation and saturation of $\mathrm{CH}_{4}$ in the pore water (Fig. 11b), which has been observed in numerous studies before (e.g. Wallmann et al., 2006; 


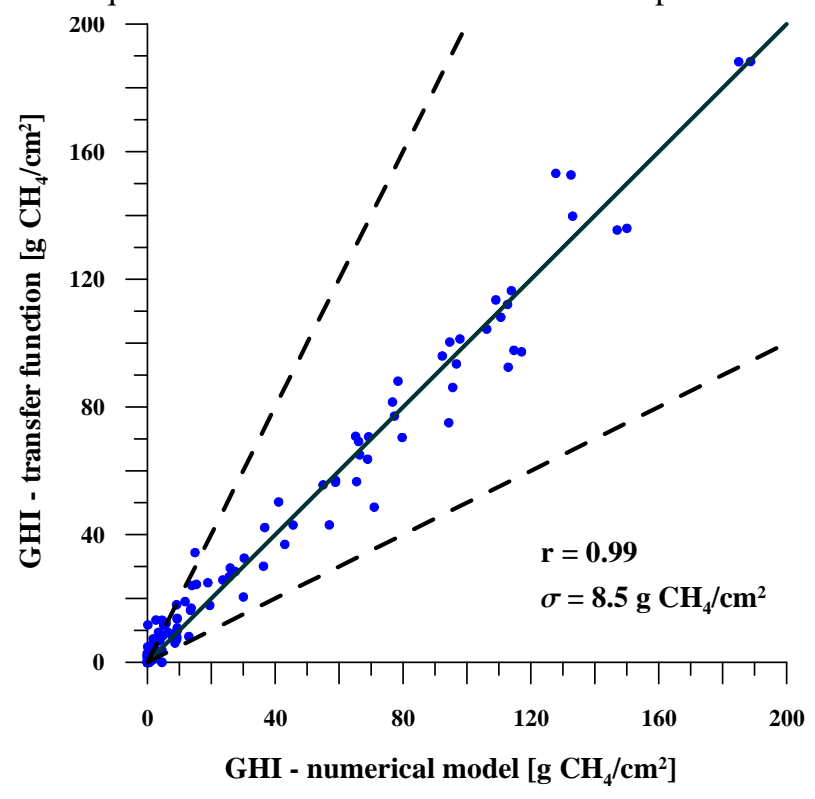

Fig. 12. Crossplot of the depth integrated GH masses estimated by the transfer function and the numerical models (sensitivity- and parameter analyses). The solid line shows the 1:1 correlation, the dotted lines the $50 \%$ deviation interval. The standard deviation $\sigma$ and the correlation coefficient $\mathrm{r}$ are indicated.

Malinverno et al., 2008). Similar to the test of the sedimentation rate (Fig. 9) and analogous to Fig. 11a, the amount of GH decreases after reaching a critical maximum in POCar of 10 to $15 \mathrm{~g} / \mathrm{m}^{2} / \mathrm{yr}$. The decrease of the GH concentration after reaching this maximum is considerably stronger at a GHSZ of $1353 \mathrm{~m}$ compared to a thinner GHSZ of $376 \mathrm{~m}$. Overall, GH inventories increase to higher values with a thicker GHSZ (e.g. at a POCar of $15 \mathrm{~g} / \mathrm{m}^{2} / \mathrm{yr}, 115 \mathrm{~g}$ of $\mathrm{CH}_{4} / \mathrm{cm}^{2}$ for a GHSZ of $1353 \mathrm{~m}$ compared to $10 \mathrm{~g}$ of $\mathrm{CH}_{4} / \mathrm{cm}^{2}$ for a GHSZ of $376 \mathrm{~m})$.

The cross-plots of both parameters indicate minimum values of POCar and GHSZ, which are required to form GH. If the GHSZ is too thin, the residence time of POC within the GHSZ is too short for sufficient degradation, and consequently the saturation level of dissolved $\mathrm{CH}_{4}$, which is necessary to produce $\mathrm{GH}$, will not be reached. The figure also indicates the minimum thickness of the GHSZ to form GH; for example this is $500 \mathrm{~m}$ at POCar of $2 \mathrm{~g} / \mathrm{m}^{2} / \mathrm{yr}$ or $250 \mathrm{~m}$ at POCar of $6 \mathrm{~g} / \mathrm{m}^{2} / \mathrm{yr}$. Overall the model implies that hydrates may form only when the GHSZ exceeds 150 to $200 \mathrm{~m}$ (Fig. 11a). This result is in good agreement with the general depth of the BSR at LGF on the upper continental margins of $>200 \mathrm{~m}$ (e.g. $240 \mathrm{mbsf}$ on the northern Cascadia margin; Riedel et al., 2006; 200 mbsf on the Svalbard margin; Hustoft et al., 2009). However, GH can still be formed at a lower thickness of the GHSZ if fluid flow and/or gas ebullition are involved (e.g. Torres et al., 2004; Haeckel et al., 2004). Likewise minimum values can also be derived for POCar. As outlined before, if the input of POC is too small due to lower sedimentation rates, most of the POC is degraded by sulphate reduction, and hence only little or no GH can form. Figure $11 \mathrm{~b}$ shows that a POCar of $\sim 0.8 \mathrm{~g} / \mathrm{m}^{2} / \mathrm{yr}$ (corresponding to a SR of $10 \mathrm{~cm} / \mathrm{kyr}$ and an initial POC concentration of 1.2 wt. \%) is a threshold value, below which $\mathrm{CH}_{4}$ can not be sufficiently accumulate in most continental margins (GHSZ thinner than $1200 \mathrm{~m}$ ).

Each of the model series indicated in Fig. 11 can be fitted by the following two types of equations: the GHSZ-GH relation (Fig. 11a) is best expressed by a potential function of the general form:

$\mathrm{GHI}=\left(s \cdot \mathrm{GHSZ}^{u}\right)$,

where GHI is the depth-integrated inventory of GH [ $\mathrm{g}$ of $\mathrm{CH}_{4} / \mathrm{cm}^{2}$ ]. GHSZ is in [m]. The POCar-GHI relation (Fig. 11b) is approximated by a Maxwell-type equation of the form:

$\mathrm{GHI}=v \cdot \mathrm{POCar} \cdot \exp \left(-w^{x / \mathrm{POCar}} / y\right)+z$

The differences between the fit-functions in both series of runs are caused by variation of the coefficients $s, u, v, w, x$, $y$ and $z$. The choice of coefficients depends on POCar (Eq. 4, Fig. 11a) and GHSZ (Eq. 5, Fig. 11b).

For the derivation of a general transfer function of POCar and GHSZ, Eq. (4) and Eq. (5) were combined by including the GHSZ-term (Eq. 4) into Eq. (5) in order to ensure that the gradients increase with increasing GHSZ and to consider the decrease of GH concentrations beyond a threshold value of POCar (Fig. 11b). A second GHSZ-term was included in the exponent to reproduce the shift of the GH maximum for thicker GHSZ. The constants were determined using the method of least squares for all data resulting from the parameter analysis. The resulting transfer function is (solid lines in Fig. 11):

$\mathrm{GHI}=a \cdot \mathrm{POCar} \cdot \mathrm{GHSZ}^{b} \cdot \exp \left(-\mathrm{GHSZ}^{c / \mathrm{POCar}} / d\right)+e$,

with $a=0.00214, b=1.234, c=-3.339$,

$$
d=0.3148, e=-10.265 .
$$

GHI is the depth-integrated GH inventory in [ $\mathrm{g}$ of $\mathrm{CH}_{4} / \mathrm{cm}^{2}$ ], POCar is the accumulation rate of POC in $\left[\mathrm{g} / \mathrm{m}^{2} / \mathrm{yr}\right]$, and GHSZ is the thickness of the GH stability zone in [m]. Negative GHI values generated by the transfer function indicate the absence of GH in the considered sediment column.

\section{Test and application of the transfer function}

To perform a preliminary test and verification of the accuracy of the transfer function (Eq. 6) we calculated the GH content for all parameterizations of the model runs of the sensitivity and the parameter analyses. The transfer function reproduces the modelled data quite well; most data points plot along the 1:1 correlation line (Fig. 12). The general scatter is moderate, however, it is more pronounced at lower concentrations, 
where errors of more than $50 \%$ occur. Overall, the standard deviation $(\sigma)$ of the function is $8.5 \mathrm{~g}$ of $\mathrm{CH}_{4} / \mathrm{cm}^{2}$ and the correlation coefficient (r) is 0.99 .

In addition, the function has been applied to the ODP Sites of Costa Rica, Peru, Chile, California, Blake Ridge and Namibia, using the parameterization given in Table 1 . The results are listed in Table 3. The GH amounts calculated with the transfer function are all between 0 and $25 \mathrm{~g}$ of $\mathrm{CH}_{4} / \mathrm{cm}^{2}$ and are consistent with the results of the ODP-Site models without the additional upward fluid flow (a- and bmodels). Additionally, the validity of the transfer function was tested by comparing its results with several published studies based on direct observations, geochemical modelling and other methods (resistivity logs, chlorinity anomalies, and seismic velocity analysis; Table 4). For a better comparison the published GH concentrations have been converted into the unit $\mathrm{g}$ of $\mathrm{CH}_{4} / \mathrm{cm}^{2}$ (using a mean porosity of 0.5 and the thickness of the GH occurrence zone at the respective sites), representing the depth integrated mass of GH per unit of seafloor area.

Overall, the GH concentrations obtained with the transfer function are in accordance with the results of several modelling studies in LGF systems, such as for the northern Cascadia margin or Blake Ridge. However, there exist significant deviations for sites where local enrichments (usually restricted to permeable layers) were considered in the estimate (see examples of Blake Ridge, Northern Cascadia or Indian Margin). For example, at sites 995 and 997 at Blake Ridge the transfer function reveals only about $50 \%$ or $20 \%$, respectively, of the estimates based on chloride anomalies (Paul et al., 1996). The latter are, however, significantly affected by strong negative chlorinity peaks, which are related to distinct GH enrichments, most likely caused by fluid advection. Since this is not implicitly considered in the preceding systematic model study, the transfer function underestimates GH inventories in such cases.

The transfer function does not predict any GH for Hydrate Ridge, which is in line with results of Torres et al. (2004) and Tréhu et al. (2004) who state that strong GH enrichments at the summit (Sites 1249-1250) are due to enhanced gas flux. Away from the summit (Sites 1244-1248) there is almost no indication for $\mathrm{GH}$ formation.

An estimate of $29 \mathrm{~g}$ of $\mathrm{CH}_{4} / \mathrm{cm}^{2}$ was made for Site 1040 offshore Costa Rica (Hensen and Wallmann, 2005) applying a geochemical model, which considers fluid flow and a different kinetic approach for POC degradation. However, the transfer function does not predict any GH at this site considering a POCar of $2.3 \mathrm{~g} / \mathrm{m}^{2} / \mathrm{yr}$, because of the low sediment thickness above the décollement $(380 \mathrm{~m})$. At Site 1041 the sediment thickness within the GHSZ is about $750 \mathrm{~m}$, which results in an amount of $10.7 \mathrm{~g}$ of $\mathrm{CH}_{4} / \mathrm{cm}^{2}$ using the transfer function, which is still in the expected range.
Table 3. Comparison of the GH amounts of the ODP sites calculated in the different model runs: a) constant POC input, b) varying POC input, c) time-dependent POC input and advective fluid flow, with the transfer function, using the input data of the ODP models. In order to use the transfer function (Eq. 6) the data of the a-models included in Table 1 were used to calculate POCar. The GHSZ was deduced from BSR depths given in the respective ODP initial reports, or calculated by the respective thermal- and pressure information.

\begin{tabular}{|c|c|c|c|}
\hline \multicolumn{2}{|c|}{$\begin{array}{l}\text { ODP Site/ } \\
\text { model }\end{array}$} & \multirow{2}{*}{$\begin{array}{c}\begin{array}{c}\text { GHI (numerical model) } \\
\text { [g of } \mathrm{CH}_{4} / \mathrm{cm}^{2} \text { ] }\end{array} \\
6.2\end{array}$} & \multirow{2}{*}{$\begin{array}{c}\begin{array}{c}\text { GHI (transfer function) } \\
\text { [g of } \mathrm{CH}_{4} / \mathrm{cm}^{2} \text { ] }\end{array} \\
10.7\end{array}$} \\
\hline 1041 & a) & & \\
\hline & b) & 7.3 & 10.7 \\
\hline 1230 & a) & 10 & 1.4 \\
\hline \multirow{2}{*}{685} & a) & 26.4 & 22.7 \\
\hline & c) & 66 & 22.7 \\
\hline \multirow[t]{3}{*}{1233} & a) & 0 & 0 \\
\hline & b) & 0 & 0 \\
\hline & c) & 0.12 & 0 \\
\hline 1014 & a) & 0.55 & 0 \\
\hline \multirow[t]{2}{*}{995} & a) & 0 & 15 \\
\hline & b) & 3.0 & 15 \\
\hline \multirow[t]{2}{*}{1084} & a) & 23.7 & 3.5 \\
\hline & c) & 39.7 & 3.5 \\
\hline
\end{tabular}

Kastner et al. (2008a) estimated the average GH concentration at site 17 NGHP (Andaman Sea) to be about 17.5\% $\left(340 \mathrm{~g}\right.$ of $\left.\mathrm{CH}_{4} / \mathrm{cm}^{2}\right)$. The total variation is, however, very pronounced, ranging from 1 to $76 \mathrm{vol} . \%$ (21 to $1625 \mathrm{~g}$ of $\mathrm{CH}_{4} / \mathrm{cm}^{2}$ ). Specifically the very high percentages of pore filling are restricted to distinct ash layers, implying a lithological control on gas migration and GH formation. However, the amount calculated by the transfer function $(27.2 \mathrm{~g}$ of $\mathrm{CH}_{4} / \mathrm{cm}^{2}$ ) is within the lower range of concentrations and may represent the regional background of biogenic GH formation in this region. Kastner et al. (2008a) also report a similar range of GH concentrations for sites 10/21 NGHP (Indian continental margin), which is not included in Table 4. Because GH occurrences at this location are restricted to shallow depths (25-160 mbsf) only and essentially formed by fracture controlled gas migration (Kastner et al.; 2008a), the application of the transfer function would reveal no formation of GH.

It should be emphasized again that the function gives mostly lower GHI values than obtained by other methods at high gas flux sites since the ascent of methane with rising fluids and gases is not considered in the model. These additional transport pathways are not included in the transfer function because fluid and gas flow are strongly variable in space and time, and hence very difficult to constrain and to generalize. At present, the function predicts the potential of $\mathrm{GH}$ formation via biogenic $\mathrm{CH}_{4}$ formation within the GHSZ only. In addition to this, it should be pointed out that - owing 
Table 4. Comparison of the GHI amount calculated with the transfer function to other published results (of average GH contents) obtained from several approaches, such as seismic velocity calculations, chlorinity, resistivity log or a combination of several of these methods. Other results obtained by numerical modelling are also shown. In order to use the transfer function (Eq. 6) at the sites which have been not modelled, POC values and sedimentation rates were taken from the ODP initial reports, or POCar was calculated using Eq. (3). The GHSZ was deduced from BSR depths given in the respective ODP initial reports. Published gas hydrate concentrations have been converted from vol.\% of pore space to $\mathrm{g}$ of $\mathrm{CH}_{4} / \mathrm{cm}^{2}$ (considering a mean porosity of 0.5 and the thickness of the gas hydrate-enriched sediment at each site) representing the depth integrated mass of GH per unit area of seafloor.

\begin{tabular}{|c|c|c|c|c|}
\hline \multirow[b]{2}{*}{ Setting } & \multicolumn{2}{|c|}{$\mathrm{GHI}\left[\mathrm{g}\right.$ of $\left.\mathrm{CH}_{4} / \mathrm{cm}^{2}\right]$} & \multirow[t]{2}{*}{ Approach } & \multirow[t]{2}{*}{ Reference } \\
\hline & transfer function & published data & & \\
\hline \multicolumn{5}{|l|}{ Blake Ridge } \\
\hline Sites 995/997 & $15 / 7.8$ & $81-113^{*}$ & Seismic velocity & $\begin{array}{l}\text { Paull et al., 1996; } \\
\text { Dickens et al., 1997 }\end{array}$ \\
\hline Site 995 & 15 & $29.7^{*}$ & Chlorinity & Paull et al., 1996 \\
\hline Site 997 & 7.8 & $42.0^{*}$ & Chlorinity & Paull et al., 1996 \\
\hline Site 997 & 7.8 & $26.2^{* *}$ & Numerical model & Davie and Buffett, 2003 \\
\hline Site 997 & 7.8 & $5.1^{* *}$ & Numerical model & Wallmann et al., 2006 \\
\hline \multicolumn{5}{|l|}{ Hydrate Ridge } \\
\hline Sites $1244-1248$ & 0 & $<19$ & Various approaches & Tréhu et al., 2004 \\
\hline Site 889 & 0 & $13^{* *}$ & Numerical model & Davie and Buffett, 2003 \\
\hline \multicolumn{5}{|l|}{ Northern Cascadia } \\
\hline Sites $1325-1327$ & $0-0.5$ & $0.4^{* *}-0.8^{* *}$ & Numerical model & Malinverno et al., 2008 \\
\hline Sites $1325-132$ & $0-0.5$ & $57^{*}$ & Various approaches & Torres et al., 2008 \\
\hline \multicolumn{5}{|l|}{ Costa Rica } \\
\hline Site 1041 & 10.7 & $29^{* *}$ & Numerical model & $\begin{array}{l}\text { Hensen and Wallmann, 2005 } \\
\text { (for nearby ODP Site 1040) }\end{array}$ \\
\hline \multicolumn{5}{|r|}{ (1) } \\
\hline Site 859 & 10 & $<17.5$ & Seismic velocity & Brown et al., 1996 \\
\hline Site 859 & 10 & $<40$ & Chlorinity & Brown et al., 1996 \\
\hline \multicolumn{5}{|l|}{ Andaman Sea } \\
\hline Site17 (NGHP) & 27.2 & $374^{*}(21$ to 1625$)$ & Chlorinity & Kastner et al., 2008a \\
\hline
\end{tabular}

* Considering focused GH enrichments in distinct layers.

** Results of numerical modelling considering fluid flow.

to the simplicity of the approach - it is based on a number of simplifications which may bias the result at any specific site. Two important assumptions may be mentioned here, which are: (i) the systems are at or close to steady-state and (ii) POCar can be sufficiently assessed by the relation between POC content and sedimentation rate (Fig. 10). As outlined above, the model results (Figs. 2-7) indicate, however, that, on average, the error caused by false estimations of these parameters is relatively low. In any case, there are no useful alternatives available to these assumptions in order to derive a generalized approach of estimating sub-seafloor GH concentrations.

\section{Conclusions}

In this study we performed a systematic analysis of the key control parameters of biogenic GH formation using the numerical model presented by Wallmann et al. (2006). The derived transfer function is based on two ubiquitously available parameters, the POC accumulation rate (POCar) and the thickness of the gas hydrate stability zone (GHSZ). Hence, we provide a simple prognostic tool for GH quantification in marine sediments which enables the estimation of GH inventories formed by in situ produced $\mathrm{CH}_{4}$ without the need of detailed information concerning the geological condition or running complex numerical models. Hence, the extrapolation to regional scales is comparatively simple.

It must be pointed out that the transfer function does not account for effects of fluid advection and methane gas ascent (HGF sites), which means that it will typically predict minimum estimates, and hence may deviate from estimates based on measured quantities at any specific site. However, at low 
Table A1. Summary of the physical properties.

\begin{tabular}{ll}
\hline Physical properties & Equation \\
\hline Porosity & $\Phi=\Phi_{f}+\left(\Phi_{0}-\Phi_{f}\right) \cdot e^{-p x \cdot x}$ \\
Burial of solids & $\omega=\frac{\omega_{f} \cdot\left(1-\Phi_{f}\right)}{1-\Phi}$ \\
Burial of pore water due & $v=\frac{\Phi_{f} \cdot \omega}{\Phi}$ \\
to sediment compaction & $v_{f f}=\frac{\Phi_{f} \cdot \omega_{f}-v_{0} \cdot \Phi_{0}}{1-2 \cdot \ln (\Phi)}$ \\
Burial of pore water and & fluid flow advection \\
Molecular diffusion & $D_{S}=\Phi^{2} \cdot D_{M}$ \\
Diffusion of GH in sediments & $D_{S}=\frac{D_{M}}{1-2 \cdot \ln (\Phi)}$ \\
\hline
\end{tabular}

gas flux sites (LGF), which represent the most common setting on a global scale, testing the function has shown that reasonable $\mathrm{GH}$ inventories are predicted.

\section{Appendix A}

\section{Model description, rate laws and boundary conditions}

All important rate laws, equations and coefficients that were used for the numerical model are listed in Table A1, A2, A3 and A4. Further information is provided by Wallmann et al. (2006).

The porosity of the sediment column $(\Phi)$ decreases from the surface $\left(\Phi_{0}\right)$ to infinite depth $\left(\Phi_{f}\right)$ of the model. The exponential decrease is defined by the depth $\mathrm{x}$ and the attenuation factor px. The transport of the sediment and the species POC, PON, GH, FG and adsorbed $\mathrm{NH}_{4}$ (ADS) is given as the burial of solids $(\omega)$ and is determined by the sedimentation rate at infinite depth $\left(\omega_{f}\right)$. The transport of the pore water $(v)$ is defined by the sedimentation rate and the reduction of the velocity caused by the decreasing pore space due to sediment compaction. Additional fluid flow $\left(\mathrm{v}_{f f}\right)$ is included by the upward fluid velocity $\left(v_{0}\right)$. The transport of the dissolved species $\left(\mathrm{CH}_{4}, \mathrm{SO}_{4}, \mathrm{NH}_{4}\right.$ and DIC) is defined by the burial of the pore water and the molecular diffusion $\left(\mathrm{D}_{S}\right)$. The diffusion term of each species respects the effect of tortuosity and depends on their specific diffusion coefficient.
Table A2. Summary of the rate laws of processes used in the modelling.

\begin{tabular}{|c|c|}
\hline Process & Rate law \\
\hline POC degradation & $\begin{array}{l}R_{\mathrm{POC}}=\frac{K_{C}}{C\left(C H_{4}\right)+C(\mathrm{DIC})+K_{C}} \cdot \\
\left(0.16 \cdot\left(\mathrm{age}_{\text {init }}+\mathrm{age}_{\mathrm{sed}}\right)^{-0.95}\right) \cdot C(\mathrm{POC})\end{array}$ \\
\hline Methanogenesis & $R_{M}=0.5 \cdot \frac{K_{\mathrm{SO}_{4}}}{K_{\mathrm{SO}_{4}}+C\left(\mathrm{SO}_{4}\right)} \cdot R_{\mathrm{POC}}$ \\
\hline $\begin{array}{l}\text { Anaerobic oxidation } \\
\text { of methane (AOM) }\end{array}$ & $R_{\mathrm{AOM}}=k_{\mathrm{AOM}} \cdot C\left(\mathrm{CH}_{4}\right) \cdot C\left(\mathrm{SO}_{4}\right)$ \\
\hline Sulphate reduction & $R_{\mathrm{SR}}=0.5 \cdot \frac{C\left(\mathrm{SO}_{4}\right)}{K_{\mathrm{SO}_{4}}+C\left(\mathrm{SO}_{4}\right)} \cdot R_{\mathrm{POC}}$ \\
\hline GH formation & $\begin{array}{l}\text { If } C_{\mathrm{SAT}}<C_{\mathrm{SOL}} \text { and If } C\left(\mathrm{CH}_{4}\right) / C_{\mathrm{SAT}}>1: \\
R_{\mathrm{GH}}=k_{\mathrm{GH}} \cdot\left(C\left(\mathrm{CH}_{4}\right) / C_{\mathrm{SAT}}-1\right)\end{array}$ \\
\hline GH dissociation & $\begin{array}{l}\text { If } C_{\mathrm{SOL}}<C_{\mathrm{SAT}} \text { or If } C\left(\mathrm{CH}_{4}\right) / C_{\mathrm{SAT}}<1: \\
R_{\mathrm{GHD}}=k_{\mathrm{GHD}} \cdot\left(C_{\mathrm{SAT}} / C\left(\mathrm{CH}_{4}\right)-1\right) \cdot C(\mathrm{GH})\end{array}$ \\
\hline FG formation & $\begin{array}{l}\text { If } C_{\mathrm{SOL}}<C_{\mathrm{SAT}} \text { and If } C\left(\mathrm{CH}_{4}\right) / C_{\mathrm{SOL}}>1: \\
R_{\mathrm{FG}}=k_{\mathrm{FG}} \cdot\left(C\left(\mathrm{CH}_{4}\right) / C_{\mathrm{SOL}}-1\right)\end{array}$ \\
\hline FG dissolution & $\begin{array}{l}\text { If } C_{\mathrm{SAT}}<C_{\mathrm{SOL}} \text { or If } C\left(\mathrm{CH}_{4}\right) / C_{\mathrm{SOL}}<1: \\
R_{\mathrm{FGD}}=k_{\mathrm{FGD}} \cdot\left(C_{\mathrm{SOL}} / C\left(\mathrm{CH}_{4}\right)-1\right) \cdot C(\mathrm{FG})\end{array}$ \\
\hline PON degradation & $R_{\mathrm{PON}}=R_{\mathrm{POC}} \cdot(N: C-$ ratio $)$ \\
\hline Ammonium adsorption & $R_{\mathrm{ADS}}=k_{\mathrm{ADS}} \cdot\left(1-\frac{\mathrm{ADS}}{C\left(\mathrm{NH}_{4}\right) \cdot K_{\mathrm{ADS}}}\right)$ \\
\hline
\end{tabular}

GH precipitates as soon as $\mathrm{CH}_{4}$ in pore water is supersaturated. The concentration of $\mathrm{CH}_{4}$ is controlled by the rate of methanogenesis $\left(\mathrm{R}_{\mathrm{M}}\right)$, AOM $\left(\mathrm{R}_{\mathrm{AOM}}\right)$, the coupled $\mathrm{SO}_{4}$ reduction $\left(\mathrm{R}_{\mathrm{SO}}\right)$ and $\mathrm{POC}$ degradation $\left(\mathrm{R}_{\mathrm{POC}}\right)$, and the concentrations of $\mathrm{CH}_{4}\left(C\left(\mathrm{CH}_{4}\right)\right), \mathrm{DIC}(C(\mathrm{DIC})), \mathrm{SO}_{4}\left(C\left(\mathrm{SO}_{4}\right)\right)$, POC $(C(\mathrm{POC}))$ and the formation und dissolution rate of $\mathrm{GH}(\mathrm{R}(\mathrm{GH}))$ and $\mathrm{FG}(\mathrm{R}(\mathrm{FG}))$. The formation and dissolution rates of $\mathrm{GH}$ and $\mathrm{FG}\left(\mathrm{R}_{\mathrm{GH}}, \mathrm{R}_{\mathrm{FG}}, \mathrm{R}_{\mathrm{GHD}}\right.$ and $\left.\mathrm{R}_{\mathrm{FGD}}\right)$ depends on the the saturation of $\mathrm{CH}_{4}$ in the pore water, the relation of GH stability $\left(\mathrm{C}_{\mathrm{SAT}}\right)$ to $\mathrm{FG}$ stability $\left(\mathrm{C}_{\mathrm{SOL}}\right)$, and the concentrations of $\mathrm{GH}$ and $\mathrm{FG}(C(\mathrm{GH})$ and $C(\mathrm{FG}))$. The stability of $\mathrm{GH}$ and $\mathrm{FG}$ is calculated as an three-phase equilibrium after Tishchenko et al. (2005). If the saturation level of $\mathrm{CH}_{4}$ in pore water is reached, the formation of $\mathrm{GH}$ or FG is starting.

The degradation rate of PON ( $\left.\mathrm{R}_{\mathrm{PON}}\right)$ is depending on $\mathrm{R}_{\mathrm{POC}}$. The $\mathrm{NH}_{4}$ formation rate is defined by the PON degradation rate and the adsorption rate of $\mathrm{NH}_{4}\left(\mathrm{R}_{\mathrm{ADS}}\right)$. 
Table A3. Summary of the rate expressions of the specific species used for the differential equation system.

\begin{tabular}{ll}
\hline \multicolumn{2}{c}{ Rate expressions for solid phase and pore water species } \\
\hline $\mathrm{POC}$ & $R(\mathrm{POC})=-R_{\mathrm{POC}}$ \\
$\mathrm{PON}$ & $R(\mathrm{PON})=-R_{\mathrm{PON}}$ \\
$\mathrm{SO}_{4}$ & $R\left(\mathrm{SO}_{4}\right)=-R_{\mathrm{SR}}-R_{\mathrm{AOM}}$ \\
$\mathrm{CH}_{4}$ & $R\left(\mathrm{CH}_{4}\right)=R_{\mathrm{M}}-R_{\mathrm{AOM}}-R_{\mathrm{GH}}+R_{\mathrm{GHD}}-R_{\mathrm{FG}}+R_{\mathrm{FGD}}$ \\
$\mathrm{GH}$ & $R(\mathrm{GH})=R_{\mathrm{GH}}-R_{\mathrm{GHD}}$ \\
$\mathrm{FG}$ & $R(\mathrm{FG})=R_{\mathrm{FG}}-R_{\mathrm{FGD}}$ \\
$\mathrm{NH}_{4}$ & $R(\mathrm{NH})=R_{\mathrm{PON}}-R_{\mathrm{ADS}}$ \\
$\mathrm{DIC}$ & $R(\mathrm{DIC})=R_{\mathrm{POC}}+R_{\mathrm{AOM}}$ \\
$\mathrm{ADS}$ & $R(\mathrm{ADS})=R_{\mathrm{ADS}} \cdot \frac{d_{S} \cdot(1-\Phi)}{\Phi}$ \\
\hline
\end{tabular}

Table A4. Boundary conditions and constants used for all model runs. Nomenclature after Wallmann et al. (2006).

\begin{tabular}{|c|c|}
\hline Parameter/Coefficient & Value \\
\hline Kinetic constant for AOM $\left(\mathrm{k}_{\mathrm{AOM}}\right)\left[\mathrm{cm}^{3} / \mathrm{mmol} / \mathrm{yr}\right]$ & 1 \\
\hline Kinetic constant for $\mathrm{NH}_{4}$ adsorption $\left(\mathrm{k}_{\mathrm{ADS}}\right)\left[\mathrm{mmol} / \mathrm{cm}^{3} / \mathrm{yr}\right]$ & 0.0001 \\
\hline Monod constant for $\mathrm{SO}_{4}$ reduction $\left(\mathrm{k}_{\mathrm{SO}}\right)\left[\mathrm{mmol} / \mathrm{cm}^{3}\right]$ & 0.001 \\
\hline Kinetic constant for $\mathrm{GH}$ precipitation $\left(\mathrm{k}_{\mathrm{GH}}\right)$ [wt. $\left.\% / \mathrm{yr}\right]$ & 0.005 \\
\hline Kinetic constant for $\mathrm{GH}$ dissolution $\left(\mathrm{k}_{\mathrm{GHD}}\right)$ [1/yr] & 0.02 \\
\hline Kinetic constant for FG precipitation $\left(\mathrm{k}_{\mathrm{FG}}\right)$ [vol. $\left.\% / \mathrm{yr}\right]$ & 0.5 \\
\hline Kinetic constant for FG dissolution $\left(\mathrm{k}_{\mathrm{FGD}}\right)[1 / \mathrm{yr}]$ & 0.5 \\
\hline $\mathrm{SO}_{4}$ concentration upper/ lower boundary [mmol/l] & $28 / 0$ \\
\hline $\mathrm{CH}_{4}$ concentration upper boundary $[\mathrm{mmol} / \mathrm{l}]$ & 0 \\
\hline $\mathrm{NH}_{4}$ concentration upper boundary $[\mathrm{mmol} / \mathrm{l}]$ & 0 \\
\hline Density of dry solids $\mathrm{d}_{S}\left[\mathrm{~g} / \mathrm{cm}^{3}\right]$ & 2.5 \\
\hline
\end{tabular}

Acknowledgements. This work was conducted within the project HYDRA funded by the German Science Foundation (DFG). We acknowledge additional support by the Sonderforschungsbereich 574 "Volatiles and Fluids in Subduction Zones" at Kiel University and the BMBF-funded project SUGAR. This publication is contribution No. 198 of the Sonderforschungsbereich 574 "Volatiles and Fluids in Subduction Zones" at Kiel University.

Edited by: J. Middelburg

\section{References}

Archer, D., Buffett, B., Brovkin, V.: Ocean methane hydrates as a slow tipping point in the global carbon cycle, P. Natl. Acad. Sci. USA, special feature PNAS, 106(49), 20596-20601, doi:10.1073/pnas.0800885105, 2008.

Berner, R. A.: Early Diagenesis - A Theoretical Approach, Princeton University Press, Princeton, USA, 1980.

Bhatnagar, W., Chapman, G., Dickens, G. R., Dugan, B., Hirasaki, G. J.: Generalization of gas hydrate distribution and saturation in marine sediments by scaling of thermodynamic and transport processes, AM. J. SCI., 307, 861-900, 2007.
Bhatnagar, G., Chapman, W. G., Dickens, G. R., Dugan, B., Hirasaki, G. J.: Sulphate-methane transition as a proxy for the average methane hydrate saturation in marine sediments, Geophys. Res. Lett, 35, L03611, doi:10.1029/2007GL032500, 2008.

Bohannon, J.: Weighing the Climate Risks of an untapped fossil fuel, Science, 319, 1753, doi:10.1126/science.319.5871.1753, 2008.

Brown, K. M., Bangs, N. L., Froelich, P. N., and Kvenvolden, K. A.: The nature, distribution and origin of gas hydrate in the Chile triple junction region, Earth Planet Sc. Lett., 139, 471-483, 1996.

Buffett, B. A. and Archer, D.: Global inventory of methane clathrate: sensitivity to changes in the deep ocean, Earth Planet Sc. Lett., 227, 185-199, 2004.

Burdige, D. J.: Preservation of Organic Matter in Marine Sediments: Controls, Mechanisms, and an Imbalance in Sediment Organic Carbon Budgets, Chem. Rev., 107, 476-485, 2007.

Colman, A. S. and Holland, H. D.: The global diagenetic flux of phosphorus from marine sediments to the oceans: Redox sensitivity and the control of atmospheric oxygen levels, Special Publication, Society for Sedimentary Geology, 66, 53-75, 2000.

D’Hondt, S. L., Jørgensen, B. B., Miller, D. J., Aiello, I. W., Bekins, B., Blake, R., Cragg, B. A., Cypionka, H., Dickens, G. R., Ferdelman, T., Ford, K. H., Gettemy, G. L., Guèrin, G., Hinrichs, K.- U., Holm, N., House, C. H., Inagaki, F., Meister, P., Mitterer, R. M., Naehr, T. H., Niitsuma, S., Parkes, R. J., Schippers, A., Skilbeck, C. G., Smith, D. C., Spivack, A. J., Teske, A., and Wiege, J.: Controls on microbial communities in deeply buried sediments, eastern Equatorial Pacific and Peru margin, Sites 1225-1231, Proceedings of the Ocean Drilling Program, Initial Reports, 201, 2003.

Davie, M. K. and Buffett, B. A.: A numerical model for the formation of gas hydrate below the seafloor, J. Geophys. Rev., 106(B1), 497-514, 2001.

Davie, M. K. and Buffett, B. A.: Sources of methane for marine gas hydrate: inferences from a comparison of observations and numerical models, Earth Planet Sc. Lett., 206, 51-63, 2003.

Dickens, G. R., O'Neil, J. R., Rea, D. K., and Owen, R. M.: Dissociation of oceanic methane hydrate as a cause of the carbon isotope excursion at the end of the Paleocene, Paleoceanographic Currents, 10(6) 965-971, 1995.

Dickens, G. R., Paull, C. K., Wallace, P., and the ODP Leg 164 Scientific Party: Direct measurement of in situ methane quantities in a large gas-hydrate reservoir, Nature, 385, 426-428, 1997.

Dickens, G. R.: The potential volume of oceanic methane hydrates with variable external conditions, Org. Geochem., 32, 11791193, 2001.

Dickens, G. R. and Snyder, G. T.: Interpreting upward methane flux from marine pore water profiles, Fire In The Ice, Winter, 7-10, 2009.

Dobrynin, V., Korotajev, Y., and Plyuschev, D.: Gas Hydrates: A Possible Energy Resource, in: Long-Term Energy Resources, edited by: Meyer, R. and Olson, J., Boston, MA, Pitman, 727729, 1981.

Egeberg, P. K. and Dickens, G. R.: Thermodynamic and pore water halogen constraints in gas hydrate distribution at ODP Site 997 (Blake Ridge), Chem. Geol., 153, 53-79, 1999.

Haeckel, M., Suess, E., Wallmann, K., and Rickert, D.: Rising methane gas bubbles form massive hydrate layers at the seafloor, Geochim. Cosmochim. Ac., 68(21), 4335-4345, 2004. 
Henrichs, S. M.: Early diagenesis of organic matter in marine sediments: progress and perplexity, Mar. Chem., 39, 119-149, 1992.

Hensen, C. and Wallmann, K.: Methane formation at Costa Rica continental margin - constraints for gas hydrate inventories and cross-décollement fluid flow, Earth Planet Sc. Lett., 236, 41-60, 2005.

Hester, K. C. and Brewer, P. G.: Clathrate hydrates in Nature, Annu. Rev. Mar. Sci., 1, 303-327, 2009.

Hustoft, S., Bunz, S., Mienert, J., Chand, S.: Gas hydrate reservoir and active methane-venting province in sediments on $<20 \mathrm{Ma}$ young oceanic crust in the Fram Strait, offshore NW-Svalbard, Earth Planet Sc. Lett., 284(1-2), 12-24, doi:10.1016/j.epsl.2009.03.038, 2009.

Kastner, M., Spivack, A. J., Torres, M., Solomon, E., Borole, D. V., Robertson, G., and Das, H. C.: Gas hydrates in three Indian ocean regions, a comparative study of occurrence and subsurface hydrology, Proceedings of the 6th International Conference on Gas Hydrates (ICGH 2008), Vancouver, British Columbia, Canada, 2008a.

Kastner, M., Torres, M., Solomon, E. and Spivack, A. J.: Marine Pore Fluid Profiles of Dissolved Sulfate; Do They Reflect In Situ Methane Fluxes?, Fire In The Ice, Summer, 6-8, 2008b.

Kennett, J. P., Cannariato, K. G., Hendy, I. L., and Behl, R. J.: Methane Hydrates in Quaternary Climate Change, The Clathrate Gun Hypothesis, American Geophysical Union, Washington, DC, 216 pp., 2003.

Kimura G., Silver E., Blum P., and participants a. c.: Proceedings of the Ocean drilling Programm, Initial Reports, 170, doi:10.2973/odp.proc.ir.170.1997, 1997.

Klauda, J. B. and Sandler, S. I.: Global Distribution of Methane Hydrate in Ocean Sediment, Energ. Fuel., 19, 459-470, 2005.

Liu, X. and Flemmings, P. B.: Dynamic multiphase flow model of hydrate formation in marine sediments, J. Geophys. Rev., 112, B03101, doi:10.1029/2005JB004227, 2007.

Lyle, M., Koizumi, I., Richter, C., and participants a. c.: Proceedings of the Ocean Drilling Program, Initial Reports, 167, doi:10.2973/odp.proc.ir.167.1997, 1997.

Malinverno, A., Kastner, M., Torres, M. E., Wortmann, U. G.: Gas hydrate occurrence from pore water chlorinity and downhole logs in a transect across the northern Cascadia margin (Integrated Ocean Drilling Program Expedition 311), J. Geophys. Res., 113, B08103, doi:10.1029/2008JB005702, 2008.

Middelburg, J.: A simple rate model for organic matter decomposition in marine sediments, Geochim. Cosmochim. Ac., 53, 1577$1581,1989$.

Milkov, A. V.: Global estimates of hydrate-bound gas in marine sediments: how much is really out there?, Earth. Sci. Rev., 66, 183-197, 2004.

Milkov, A. V.: Molecular and stable isotope compositions of natural gas hydrates: a revised global dataset and basic interpretations in the context of geological settings, Org. Geochem., 36(5), 681$702,2005$.

Mix, A. C., Tiedemann, R., Blum, P., and participants a. c.: Proceedings of the Ocean Drilling Program, Initial Reports, 202, doi:10.2973/odp.proc.ir.202.104.2003, 2003.

Paull, C. K., Matsumoto, R., Wallace, P. J., and participants a. c.: Proceedings of the Ocean Drilling Program, Initial Reports, 164, 334 pp., doi:10.2973/odp.proc.ir.164.1996, 1996.

Paull, C. K., Matsumoto, R., Wallace, P. J., and Dillon, W. P. (eds.):
Proceedings of the Ocean Drilling Program, Sci. Results, 164: College Station, TX (Ocean Drilling Program), 2000.

Premuzic E. T., Benkovitz C. M., Gaffney J. S., and Walsh J. J.: The nature and distribution of organic matter in the surface sediments of world oceans and seas, Org. Geochem., 4, 63-77, 1982.

Reagan M. T. and Moridis G. J.: Large-scale simulation of methane hydrate dissociation along the West Spitsbergen Margin, Geophys. Res. Lett., 36, 1-29, 2009.

Riedel, M., Willoughby, E. C., Chen, M. A., He, T., Novosel, I., Schwalenberg, K., Hyndman, R. D., Spence, G. D., Chapman, N. R., and Edwards, R. N.: Gas hydrate on the northern Cascadia margin: regional geophysics and structural framework, in: Riedel, M., Collett, T. S., Malone, M. J., and the Expedition 311 Scientists, Proc. IODP, 311: Washington, DC (Integrated Ocean Drilling Program Management International, Inc.), doi:10.2204/iodp.proc.311.109.2006, 2006.

Romankevich E. A., Vetrov A. A., and Peresypkin V. I.: Organic matter of the World Ocean, Russian Geology and Geophysics, 50, 299-307, 2009.

Sassen, R., Sweet, S. T., Milkov, A. V., DeFreitas, D. A., and Kennicutt II, M. C.: Thermogenic vent gas and gas hydrate in the Gulf of Mexico slope: is gas hydrate decomposition significant?, Geology, 29(2), 107-110, 2001.

Seiter, K., Hensen, C., Schröte, J., and Zabel, M.: Organic carbon content in surface sediments - defining regional provinces, Deep Sea Res., 51(12), 2001-2026, 2004.

Seiter, K., Hensen, C., and Zabel, M.: Benthic carbon mineralization on a global scale, Global. Biogeochem. Cy., 19, GB1010, doi:10.1029/2004GB002225, 2005.

Soloviev, V. A.: Global estimation of gas content in submarine gas hydrate accumulations, Russ. Geol. Geophys., 43, 609-624, 2002.

Suess, E., von Huene, R., and participants a. c.: Proceedings of the Ocean Drilling Program, Initial Reports, 112, 1988.

Tishchenko, P., Hensen, C., Wallmann, K. and Wong, C. S.: Calculation of the stability and solubility of methane hydrate in seawater, Chem. Geol., 219, 37-52, 2005.

Torres, M. E., Wallmann, K., Tréhu, A. M., Bohrmann, G., Borowski, W. S. and Tomaru, H.: Gas hydrate growth, methane transport, and chloride enrichment at the southern summit of Hydrate Ridge, Cascadia margin off Oregon, Earth Planet Sc. Lett., 226, 225-241, 2004.

Torres, M. E., Tréhu, A. M., Cespedes, N., Kastner, M., Wortmann, U. G., Kim, J. H., Long, P., Malinverno, A., Pohlman, J. W., Riedel, M., and Collett, T.: Methane hydrate formation in turbidite sediments of northern Cascadia, IODPExpedition 311, Earth Planet Sc. Lett., 271, 170-180, 2008.

Tréhu, A. M., Torres, M. E., Long, P. E., Torres, M. E., Bohrmann, G., Rack, F. R., Collet, T. S., Goldberg, D. S. , Milkov, A. V., Riedel, M., Schultheiss, P., Bangs, N. L., Barr, S. R., Borowski, W. S., Claypool, G. E., Delwiche, M. E., Dickens, G. R., Gracia, E., Guerin, G., Holland, M. , Johnson, J. E., Lee, Y.-J., Liu, C.S., Su, X., Teichert, B., Tomaru, H., Vanneste, M., Watanabe, M., and Weinberger, J. L.: Three-dimensional distribution of gas hydrate beneath southern Hydrate Ridge: constraints from ODP Leg 204, Earth Planet Sc. Lett., 222, 845-862, 2004.

Tromp, T. K., Van Cappellen, P. and Key, R. M.: A global model for the early diagenesis of organic carbon and organic phosphorus in marine sediments, Geochim. Cosmochim. Ac., 59(7), 
1259-1284, 1995.

Uchida, T., Lu, H., Tomaru, H., and the MITI Nankai Trough Shipboard Scientists: Subsurface Occurrence of Natural Gas Hydrate in the Nankai Trough Area: implication for Gas Hydrate Concentration, Resour. Geol., 54, 35-44, doi:10.1111/j.17513928.2004.tb00185.x, 2004.

Wallmann, K., Aloisi, G. Haeckel, M., Obzhirov, A., Pavlova, G., and Tishchenko, P.: Kinetics of organic matter degradation, microbial methane generation, and gas hydrate formation in anoxic marine sediments, Geochim. Cosmochim. Ac., 70, 3905-3927, 2006.
Wefer, G., Berger, W. H., Richter, C., and participants a. c.: Proceedings of the Ocean Drilling Program, Initial Reports, 175, 339-384, doi:10.2973/odp.proc.ir.175.1998, 1998.

$\mathrm{Xu}, \mathrm{W}$. and Germanovich, L. N.: Excess pore pressure resulting from methane hydrate dissociation in marine sediments: A theoretical approach, J. Geophys. Res., 111(BO), 1104, doi:10.1029/2004JB003600, 2006. 